\title{
ESTUDO DA ALTERAÇÃO DO ANORTOSITO DE CAPIVARITA, RIO PARDO, RS
}

\section{MILTON L. L. FORMOSO* e DIONE ALVES PINTAUDE**}

ABSTRACT Anorthositic rocks are restricted to Capivarita area in Rio Grande do Sul. Under a humid temperate climate anorthosite deeply weathers. Labradorite goes directly to kaolinitic clay minerals. Most calcium and sodium cations are leached and principally halloysite and/or b-axis disordered kaolinite are formed.

Plotting in $\log \left[\mathrm{H}_{4} \mathrm{SiO}_{4}\right]$ and $\log \frac{\left[\mathrm{Na}^{+}\right]}{\left[\mathrm{H}^{+}\right]}$diagrams analytical data of waters in probable equilibrium with anorthosite weathering products, it is observed that the composition of those waters is situated in kaolinite and montmorillonite stability fields. Using log $\left[\mathrm{H}_{4} \mathrm{SiO}_{4}\right]$ and $\log \frac{\left[\mathrm{Ca}^{+2}\right]}{\left[\mathrm{H}^{+}\right]}$as coordinates those waters are situated in montmorillonite field but very close to the montmorillonite-kaolinite boundary.

Special attention was given to the behavior of strontium which was very similar to that of calcium during the weathering. The content of strontium varies in the profile from 1020 to $70 \mathrm{ppm}$ from the base to the top.

INTRODUÇÃo O estudo da alteração do anortosito adquire importância por se tratar de uma rocha quase monominerálica e de ocorrência restrita ao Pré-Carnbriano de algumas áreas do mundo. $O$ anortosito de Capivarita constitui uma das poucas ocorrências descritas no Brasil e na América do Sul. Ademais, o maior número de ocorrências se restringe aos países de clima frio (Canadá, U.S.A. e Escandinávia), onde o intemperismo não é intenso de maneira que a alteração dessa rocha rica em plagioclásio assume especial interesse em área de clima sub-tropical.

A área estudada dista aproximadamente $143 \mathrm{~km}$ de Porto Alegre, $118 \mathrm{~km}$ na direção oeste, pela rodovia Br-290, até a localidade de Pedro Nunes e daí cerca de $25 \mathrm{~km}$ na estrada Pedro Nunes-Encruzilhada, na direção sul. (Fig. 1)

O fenômeno de alteração desta rocha pode ser observado nas diversas boçorocas em formação na região da Folha de Capivarita. A maior dessas foi o local do estudo, onde foram coletados e analisados dez perfis de solo. (foto 1 ).

Trabalhos anteriores Alguns pesquisadores no Brasil vem se dedicando ao estudo de alteração de rochas.

Levi e Melfi (1972) estudaram a alteração de rochas ígneas básicas e anfibolitos sujeitos a condições climaticas sub-tropicais úmidas. Os autores apontam uma tendência média de comportamento para os elementos químicos durante o processo de alteração. Para as rochas ígneas básicas, há uma perda gradativa de cálcio, sódio, magnésio, potássio e silício em ordem decrescente de facilidade.

* UFRGS - CIENTEC - CNPq.

** UFRGS - CNPq. 


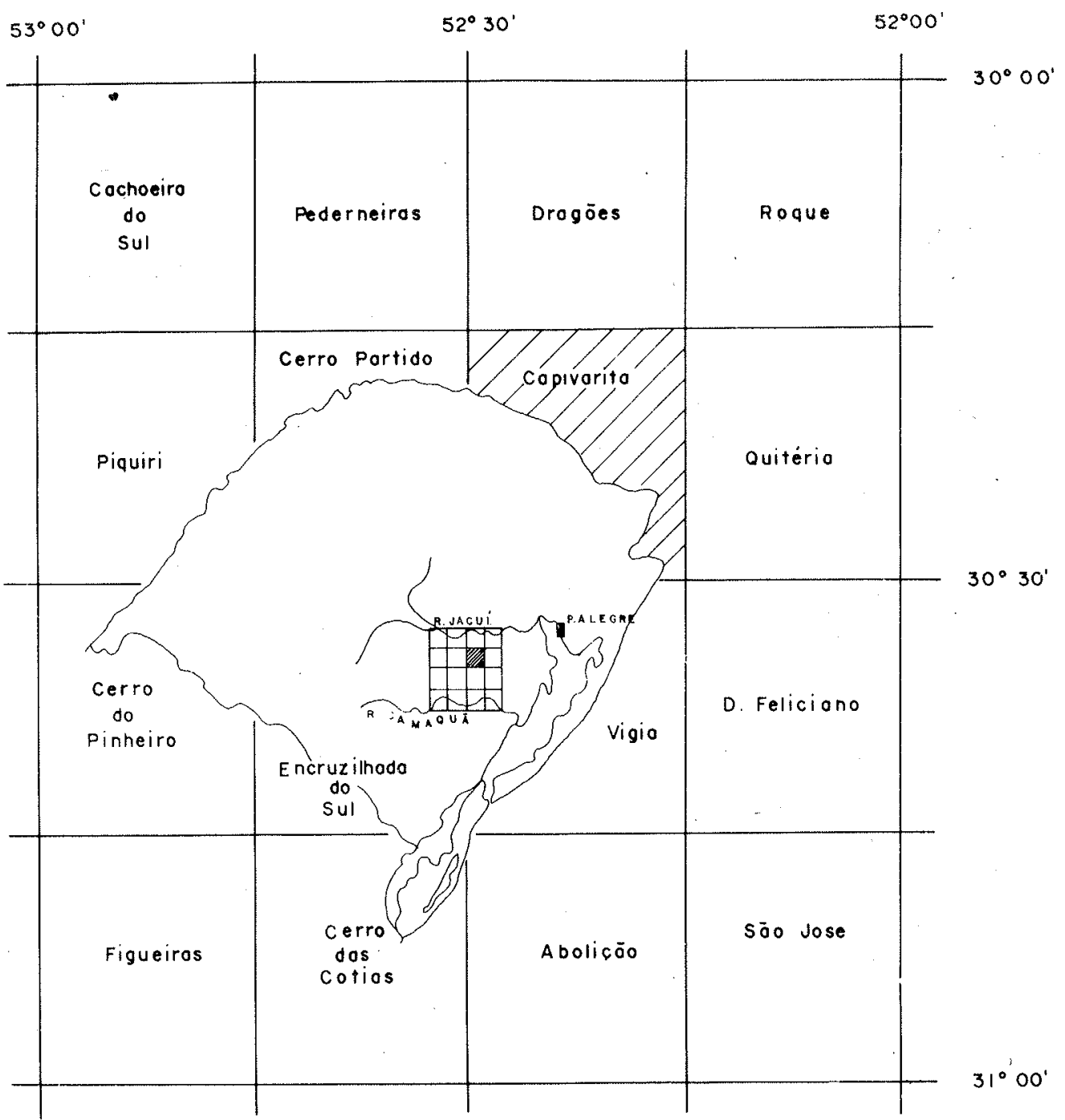

Figura 1 - Mapa índice regional e local

Comparando as rochas ígneas básicas com anfibolitos, os autores observaram que nos últimos, silício, alumínio é potássio são retidos mais facilmente e o vanádio mais facilmente perdido. A perda de cálcio se torna quase igual à de magnésio. Para chumbo, boro, manganês, titânio e zircônio, as diferenças são insignificantes.

Sighinolfi, et al. (1973) estudaram as transformações químicas e mineralógicas que ocorrem durante o intemperismo de rochas granulíticas do embasamento brasileiro. Neste trabalho, é estudado o mecanismo de formação dos solos gibsíticos, caoliníticos ou caolinítico-gibsíticos, sob um intemperismo tropical. 


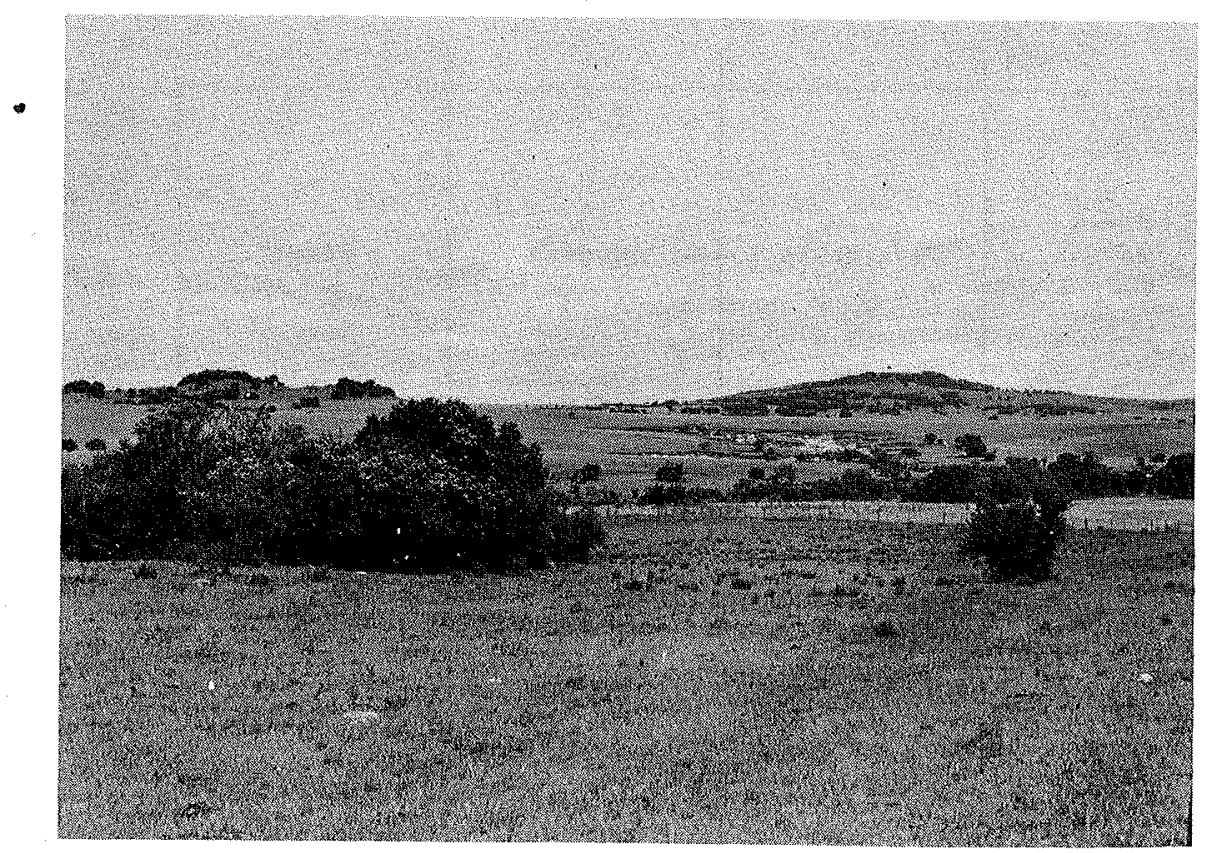

Foto 1 - Vista geral da planície anortosítica mostrando ao fundo a boçoroca grande

Melfi e Pedro (1974) realizaram um estudo experimental buscando dados sobre o comportamento na formação dos diversos óxidos e hidróxidos de manganês, a fim de relacioná-lo com o processo natural de formação dos mesmos.

Melfi et al. (1976), em recente estudo sobre a alteração geoquímica dos itabiritos, em regiões tropicais úmidas, estudaram a evolução dos minerais primários, apresentando o quartzo acentuada dissolução hidrolítica e a hematita se mostra instável. Nos neoformados, ficou constatada a presença de goethita. A ausência dos argilo-minerais férricos também foi observada.

Moniz et al. (1973), em trabalho realizado sobre a alteração de rochas basálticas do Estado de São Paulo, deram ênfase ao estudo da mobilidade dos elementos constituintes das rochas durante o intemperismo e a caracterização mineralógica dos produtos de alteração.

Silva F! (1972) estudou a alteração de basalto de amostras coletadas em diferentes regiões do Rio Grande do Sul, nas quais relacionou a ocorrência dessas rochas com os solos delas derivados, dando ênfase especial ao estudo dos argilo-minerais.

Sartori et al. (1973) desenvolveram o estudo de alteração de rocha na Formação Serra Geral (região de Santa Maria, RS), contribuindo com dados para o conhecimento dos mecanismos de decomposição das rochas basálticas.

Roisenberg (1974) estudou rochas basálticas e diferenciados ácidos da Formaçã̀o Serra Geral (Bacia do Paraná), descrevendo os argilo-minerais da rocha fresca e os materiais evoluídos do intemperismo incipiente. 
Os trabalhos realizados até então na área de Capivarita se restringem mais a mapeamento e descrição das rochas, pouco abordando a alteração do anortosito.

Formoso e Carraro (1962), Formoso et al. (1966), Formoso e Carraro (1968) e Formoso (1972) estudaram a área de Capivarita.

MÉTODOS DE TRABALHO A composição mineralógica das amostras foi conhecida através da separação das diferentes frações granulométricas ou seja, $>2 \mu, 2-20 \mu$ e $20-60 \mu$; estas frações foram estudadas por difração de raios X, usando equipamento Norelco, tubo de cobre, $35 \mathrm{kV}$ è $20 \mathrm{~mA}$, velocidades desde 2. $(2 \theta)$ a $1 / 4^{\circ}$ ( $2 \theta$ ) por minuto (Instituto de Geociências - UFRGS).

Para determinação do plagioclásio, foi usado o valor $\gamma=2 \theta(220)+2 \theta[(131)-$ - 2(131)] (Smith e Gay, 1958).

Os elementos maiores foram analisados, por via úmida, no Instituto de Geociências - UFRGS. Foram determinados os seguintes óxidos: $\mathrm{SiO}_{2}, \mathrm{Al}_{2} \mathrm{O}_{3}, \mathrm{Fe}_{2} \mathrm{O}_{3}$, $\mathrm{CaO}, \mathrm{MgO}, \mathrm{FeO}, \mathrm{TiO}_{2}, \mathrm{Na}_{2} \mathrm{O}, \mathrm{K}_{2} \mathrm{O}, \mathrm{P}_{2} \mathrm{O}_{5}, \mathrm{H}_{2} \mathrm{O}(-)$ e $\mathrm{H}_{2} \mathrm{O}(+)$.

Os elementos menores foram determinados por espectrografia óptica. Foi utilizado o método de energia total (Herz e Dutra, 1960).

Em amostra de concreção calcária, foi determinado o estrôncio. A amostra foi tratada e dissolvida em ácido acético $3 \mathrm{~N}$ até não mais desprender $\mathrm{CO}_{2}$. A suspensão foi filtrada e evaporada. $O$ resíduo final foi levado ao forno e examinado por via espectroquímica.

As eletromicrografias foram realizadas no Setor de Microscopia Eletrônica do Centro de Energia Nuclear da Agricultura, Piracicaba, SP. O pó de argila foi misturado com parlódio dissolvido em acetado de amila; uma membrana é colocada na grade a examinar. $O$ aumento foi de 30.000 vezes.

DESCRIÇÃO DO ANORTOSITO O anortosito de Capivarita foi descrito por Formoso e Carraro (1962) e Formoso (1972).

Estratigraficamente, está incluído no Grupo Cambaí (Picada e Tessari, 1966).

A idade real do anortosito, por analogia com outros corpos anortosíticos do mundo, deve ser da ordem de 1.000 milhões de anos. A idade medida para o anortosito, (K-Ar em plagioclásio) foi de $564 \pm 32$ milhões de anos; esta, deve corresponder ao último evento térmico sofrido pela rocha.

$\mathrm{Na}$ folha de Capivarita, o anortosito ocupa uma área de $77 \mathrm{~km}^{2}$. Uma extensão de $49 \mathrm{~km}^{2}$ constitui a planície anortosítica, ocupando a parte centro-oeste; outra área, na parte centro-leste, ocupa $23 \mathrm{~km}^{2}$; e uma terceira, ao sul $5 \mathrm{~km}^{2}$. Além disso, pequenos corpos de anortosito aparecem isolados no granito de Encruzilhada. Xenólitos de anortosito no granito e diques de granitos cortando o anortosito não são incomuns. A principal área de ocorrência no anortosito tem aproximadamente $8 \mathrm{~km}$ de comprimento na direção $\mathrm{NS}$ por $6,5 \mathrm{~km}$ de largura média, alogando-se na parte nordeste.

O relevo relacionado ao anortosito é característico, contrastando com granito de Encruzilhada. Uma imensa planície com vegetação rasteira, constituída de gramíneas, Piptochaetium sp. e Anoxopus sp., gravatá, Eryngium nudicaule, e Creveulia acuminata (Compositae), é a zona principal de afloramento do anortosito. Diques de anfibolito sobressaem na topografia anortosítica. A formação dessa planície tem em parte sua explicação na maior facilidade de alteração do anortosito em comparação ao granito topograficamente mais elevado. 
$O$ anortosito apresenta cor branco-acinzentada, com pontuações pretas e verde-escuras disseminadas. A textura varia de granular média a grossa; transige em álguns locais parapegmatóide. Os grãos variam de $1 \mathrm{~mm}$ a alguns $\mathrm{cm}$, chegando o plagioclásio a atingir 9 a $10 \mathrm{~cm}$. Cerca de $95 \%$ da rocha é constituída por plagioclásio, geralmente anédrico. Sua composição varia em geral de $\left(\mathrm{An}_{50} a \mathrm{An}_{62}\right)\left(\mathrm{Fo}_{\mathrm{o}}\right.$ tos 2,3 e 4). Está alterado a sericita e a caolinita que são relativamente abundantes. Aparecem ainda minerais como clorita, piroxênios, anfibólios, opacos, esfênio, carbonatos, quartzo, sericita, pistacita, zoisita e apatita. Todos esses minerais ocorrem em pequenas quantidades, formando aglomerações ou incluídos no plagioclásio.

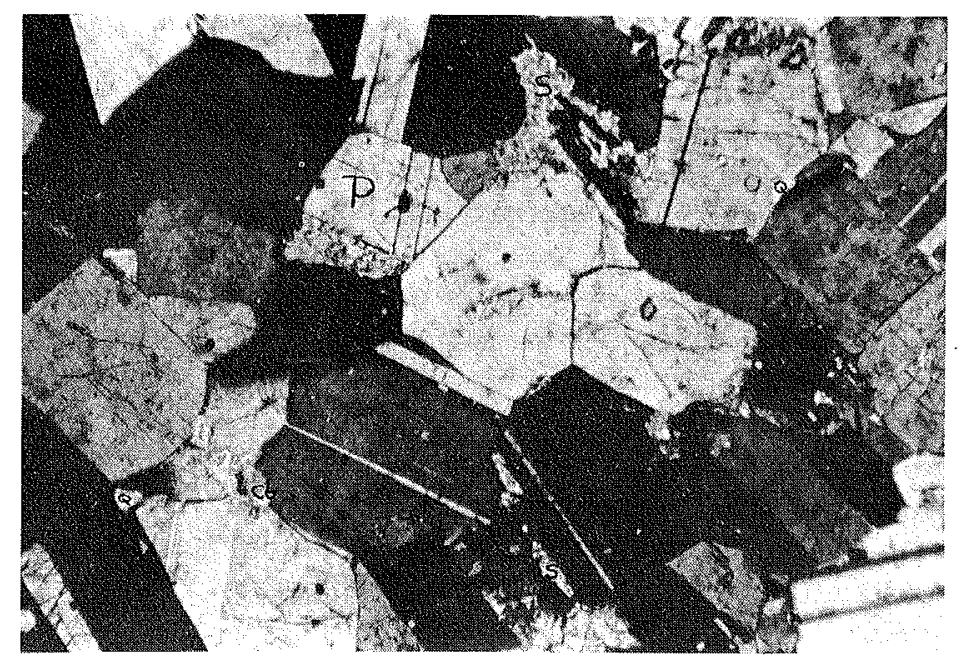

Foto 2 - Plagioclásio $(\mathrm{P})$ alterado a sericita $(\mathrm{S})$ e carbonato $(\mathrm{Cb})$. O quartzo (Q) intergranular aparece incluído. Aumento $120 \mathrm{x}$

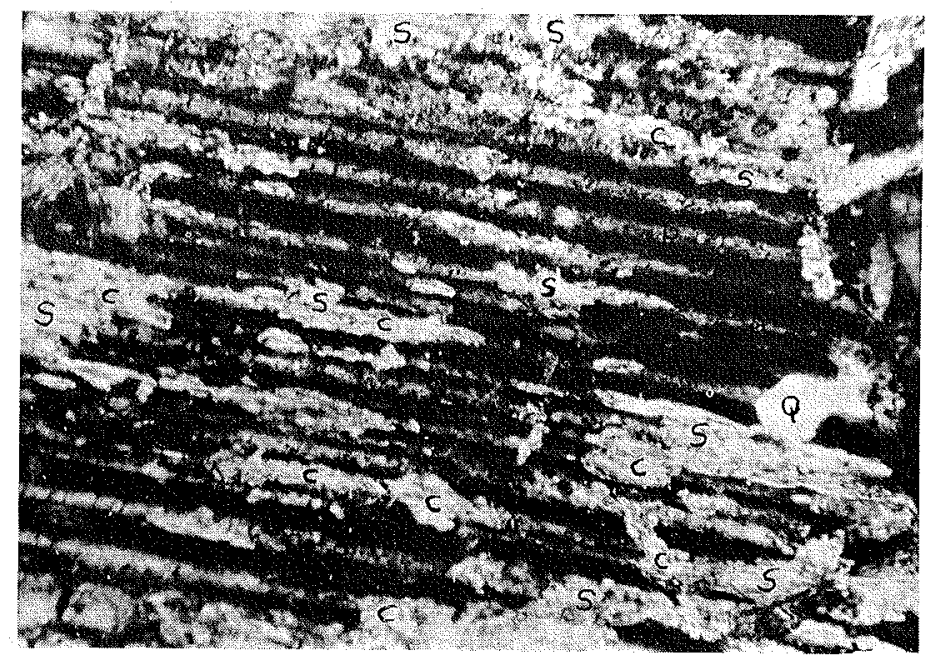

Foto 3 - Plagioclásio intensamente alterado a sericita (S) e caolinita (C), orientadas paralelamente às maclas. Aparecem incluídos, cristais arredondados de quartzo. Aumento 300x 


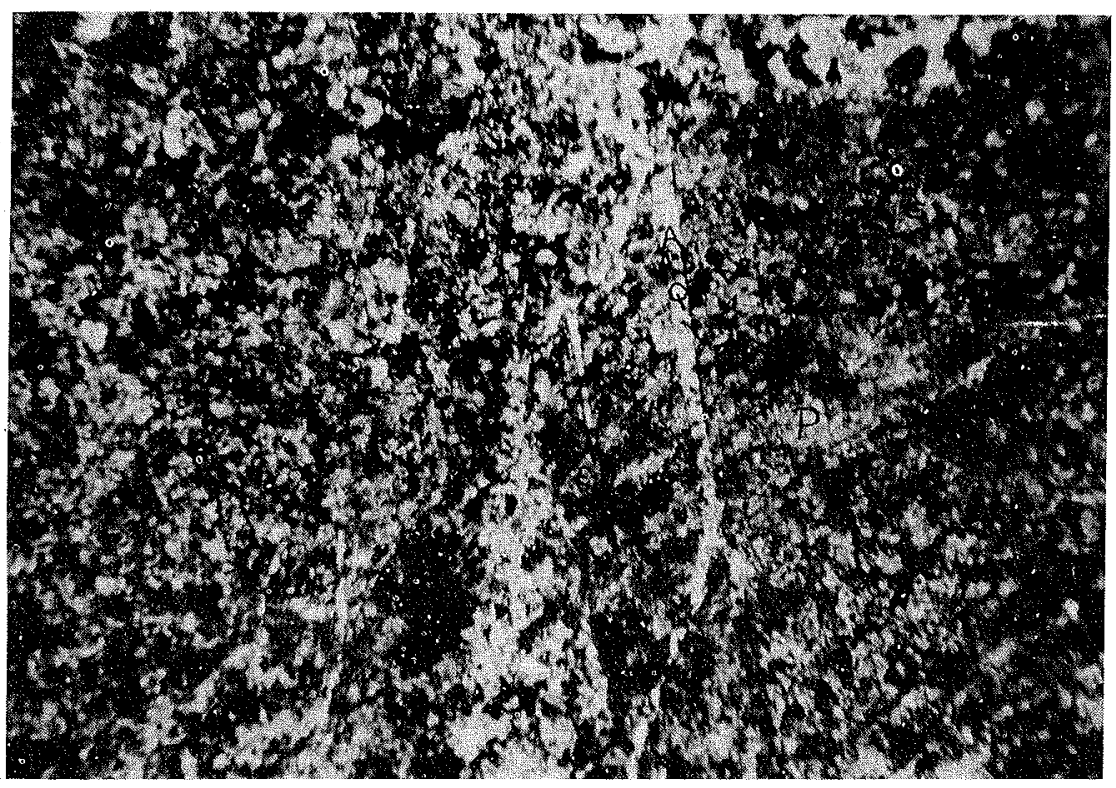

Foto 4 - Plagioclásio intensamente alterado a sericita (S), pistacita (E.P.) e caolinita (C). Vênulo de albita $(\mathrm{Ab})$ com algum quartzo (Q) granular. Aumento 120x

ESTUDO DA ALTERAÇÃO DA ROCHA O processo predominante na alteração do anortosito é o da monossialitização (Harrassowitz, 1962).

Segundo Pedro (1964), a monossialitização é controlada principalmente por um alto índice pluviométrico (superior a $500 \mathrm{~mm}$ ) e pela temperatura média da área. Drenagem elevada aparece como o terceiro fator a ser considerado e aquela o é comprovadamente pela eliminação dos cátions, fato observável nos perfis dos solos.

A altitude média da região Capivarita-Encruzilhada é de $435 \mathrm{~m}$. A precipitação é de $1.635 \mathrm{~mm}$ anuais. A temperatura média anual é de $16,6^{\circ} \mathrm{C}$ e a umidade relativa em média no ano, $82 \%$. Insolação global anual é de 2.405 horas.

A arenização na boçoroca é comum. Os grãos constituintes dos minerais do anortosito são incipientemente alterados, constituindo na sua maior parte uma areia branca (arena).

Essa areia é predominantemente constituída por plagioclásio associado a alguns minerais de alteração como caolinita, óxidos de ferro e de manganês. Também se observa nas partes mais baixas da boçoroca, concentrações de minerais pesados.

Próximo à base dos perfis e mesmo ao longo da boçoroca, ocorrem matacões e seixos de anortosito e de quartzo, estes oriundos de pequenos diques de pegmatitos ou veios que cortam o anortosito. Observa-se também a presença de rochas mais máficas, alteradas, associadas ao anorrosito, constituídas por hornblenda, vermiculita e plagioclásio. Essas rochas apresentam comumente estruturas lineares. e planares. Junto ao material da alteração, aparecem concreções calcárias formadas pela ação de águas bicarbonatadas sobre os grãos de plagioclásio. Ainda, são 
comuns concreções de óxido de ferro e manganês formadas por fenômenos superficiais. São, em muitos locais, encontrados óxidos de ferro e manganês, formando capas ou finos níveis de couraças nas rochas.

Descrição dos perfis Pela observação de campo, utilizando os métodos propostos pela Sociedade Brasileira de Ciência do Solo e devido à similaridade apresentada entre os perfis estudados, tem-se a seguinte descrição geral:

Horizonte $\mathrm{A}_{1}, 0-35 \mathrm{~cm}$; preto - $(2,5 \mathrm{YR} 2 / 0$ úmido); franco argiloso; fraca, grande colunar que se quebra em blocos sub-angulares; friável, duro, ligeiramente plástico e ligeiramente pegajoso; transição clara e plana. Aparecem restos de vegetais e, em locais, nota-se grânulos de quartzo de cor amarelo-parda; (foto 5)

$\mathrm{B}_{y}, 35-80 \mathrm{~cm}$; preto - (10YR 2/1, úmido); argila, moderada e forte, grande, prismática, que se desfaz em blocos angulares; cerosidade forte e abundante; presença de "slickensides", muito duro, firme, plástico e pegajoso. Observa-se também nesse horizonte grânulos de quartzo de até $1 \mathrm{~cm}$ de diâmetro;

$\mathrm{C}_{1}, 80-180 \mathrm{~cm}$; bruno avermelhado - $(2,5 \mathrm{YR} 5 / 4$, úmido $)$; argila, fraca e moderada, grandes, blocos angulares, presença de "slickensides"; presença de concreções calcárias e manganosas. $\mathrm{O}$ anortosito parcialmente intemperizado é o constituinte principal desse horizonte (foto 6).

$\mathrm{C}_{\mathrm{z}}$, mais de $180 \mathrm{~cm}$; bruno acinzentado - (10YR 5/2, seco); anortosito alterado com presença de concreções de manganês e deposição eluvial de argila e material orgânico em fendas. As concreções são arredondadas, superficialmente irregulares. Aparecem ainda, grânulos de quartzo de até $1,5 \mathrm{~cm}$, plagioclásio alterado, alguns opacos (ilmenita ou rutilo).

Baseado nas características morfológicas, os solos podem ser classificados no grande grupo dos Brunizem Hidromórficos, segundo o Sistema Brasileiro e conforme os critérios utilizados no levantamento de reconhecimento dos solos do Estado do Rio Grande do Sul.

Estudo mineralógico dos perfis Separações granulométricas, compreendendo as fraçōes $<2 \mu, 2-20 \mu$ e $20-60 \mu$ e $>60 \mu$ foram estudadas com a finalidade de determinar a assembléia de minerais constituintes. As três primeiras frações foram analisadas por difração de raios X e a última por exame à lupa binocular.

a) Fração argila $<2 \mu-$ Os diversos horizontes são constituídos quase que exclusivamente por argilo-minerais do grupo da caolinita (caolinita, haloisita e caolinita desordenada). Em algumas amostras, a caolinita se apresenta com um aspecto bem cristalizado. Em outras, aparecem picos arredondados, indicando uma má cristalinidade ou uma possível mistura de caolinita e haloisita.

Para algumas amostras, na base dos perfis, aparece esmectita, porém em pequena quantidade. Sob o ponto de vista de ambiente de alteração, esse fato é de singular importância, indiçando que o estado de alteração mais avançado caracteriza os perfis e o argilo-mineral em equilíbrio é a caolinita; a esmectita deve ser uma fase transitória no perfil porque mesmo nos níveis inferiores deste não há aumento da quantidade desse mineral. Ainda, como a quantidade de esmectita é pequena, não se pode estudá-la em detalhe, tornando-se difícil determinar a espécie no grupo. Por analogia de composição química, é lícito pressupor-se uma esmectita dioctaédrica aluminosa (montmorilonita) que deveria ser formada a partir do plagioclásio. Ainda na fração $<2 \mu$, em menores quantidades, aparece 
o interestratificado I-M, formado por intemperismo de sericita ou ilita. Em algumas amostras, aparece um pico de $8,50 \mathrm{~A}^{\circ}$ que poderia indicar a ocorrência de anfibólio. $O$ quartzo é raro nessa fração, sugerindo que seja proveniente da rocha. A clorita e a vermiculita, que também aparecem, são alterações dos máficos. A ausência de feldspatos (plagioclásios) nas frações finas significa, sobretudo, que a alteração desses minerais é notadamente química e não física. $O$ plagioclásio é alterado a mineral do grupo caolinita. (Figs. 2, 3, 4)
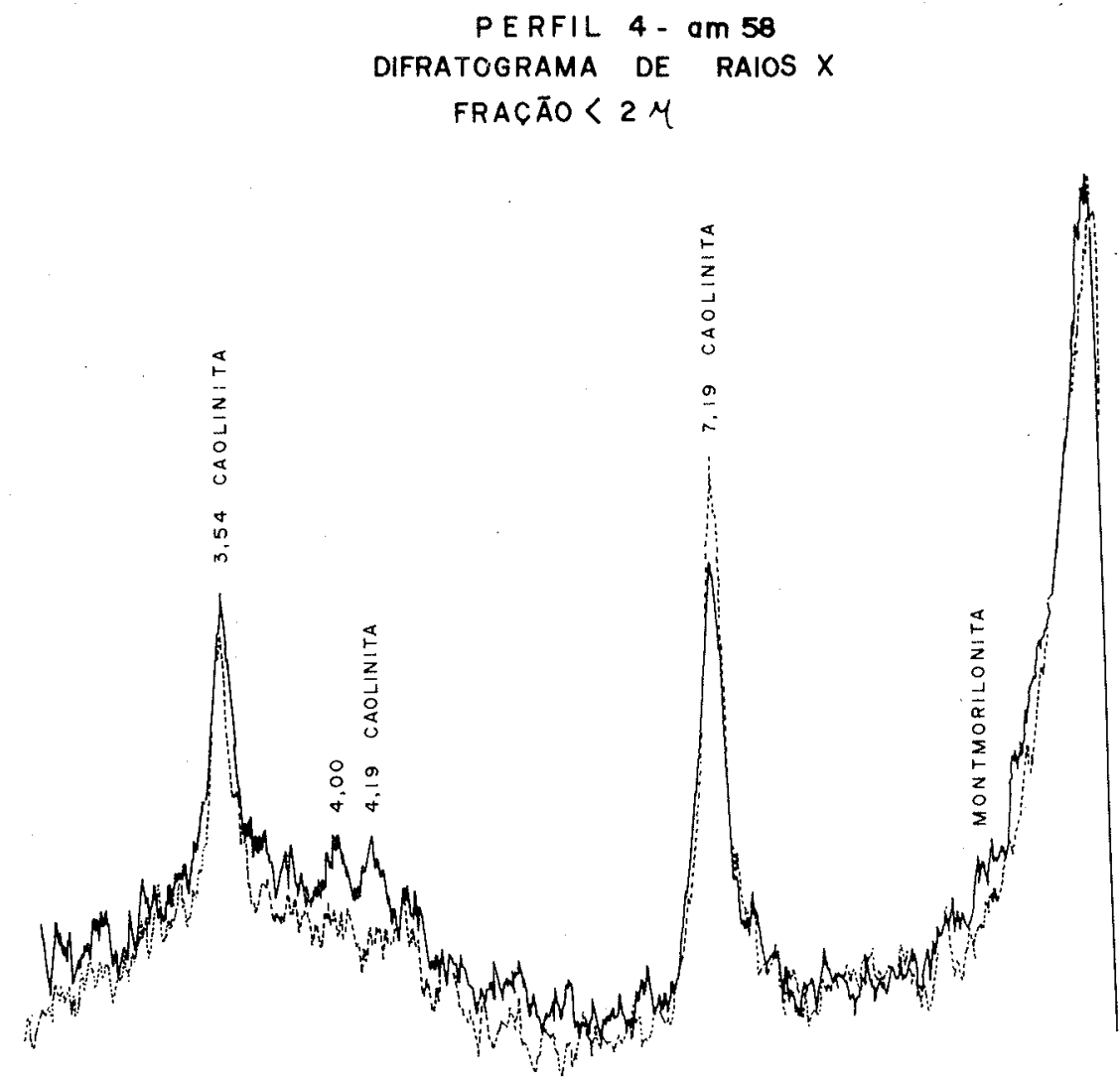

$\begin{array}{lllllllllllllll}30 & 28 & 26 & 24 & 22 & 20 & 18 & 16 & 14 & 12 & 10 & 8 & 6 & 4 & 2\end{array}$

Figura 2 


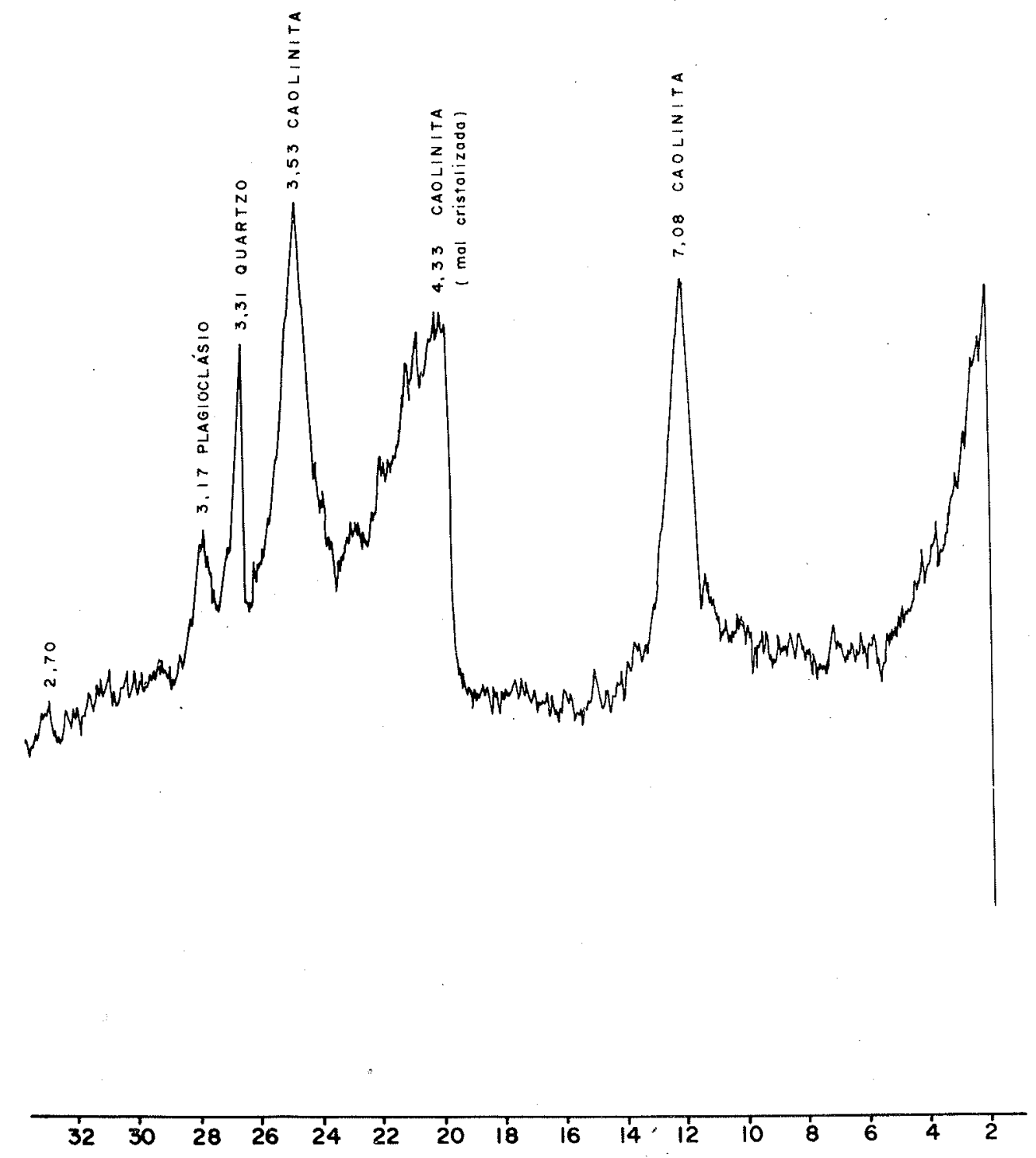

Figura 3 


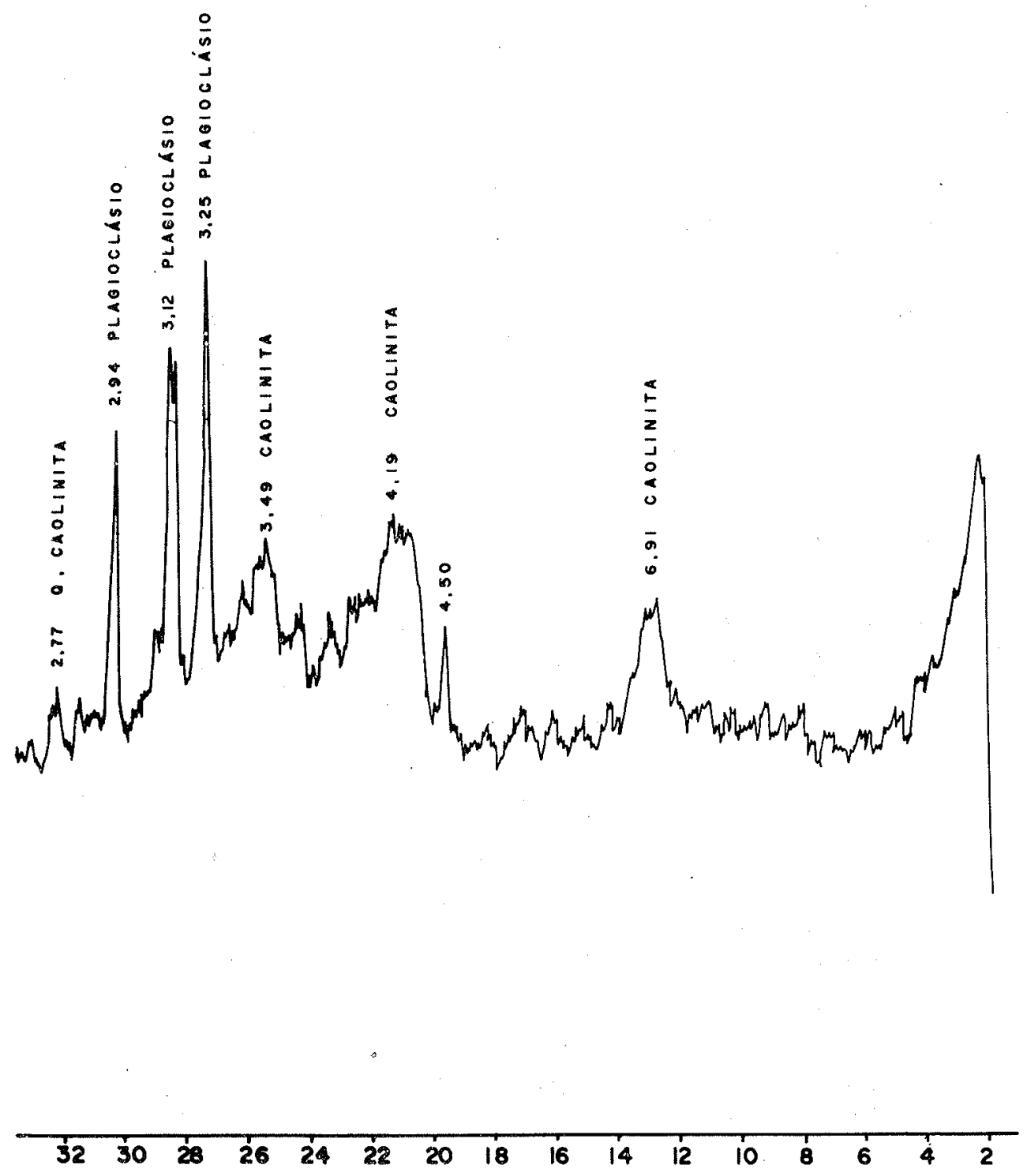

Figura 4 
b) Fração $2 \mu-20 \mu$ e $20 \mu$ - $60 \mu$ - Nas frações de granulometria maior, predominam quartzo e feldspato. Subordinadamente, aparecem o interestratificado I-M,"clorita ou vermiculita e hornblenda.

O exame das frações maiores que $60 \mu$ apresentou, em média, $98 \%$ de plagioclásio; opacos e vermiculita constituem, para a maioria das amostras, os minerais subordinados.

Nos difratogramas de raios $\mathrm{X}$, não foi observada gibbsita. A rázão explicável se relaciona com a lixiviação incompleta da sílica em conseqüência da topografia (área de planície).

A formação de concreções calcárias no horizonte $\mathrm{C}$ é mais uma indicação da lixiviação do cálcio, que assim permanece no perfil, precipitando como caŕbonato. Pelo estudo microscópico realizado, os minerais identificados são: labradorita, carbonato (calcita), quartzo, sericita, epídoto e hornblenda.

O plagioclásio está substituído por calcita de uma maneira generalizada e intensa, cerca de $50 \%$, sobretudo ao longo das microfissuras e geminações. Freqüentemente, restam apenas vestígios de um antigo grão pseudomorfisado por calcita que raramente está bem cristalizada. Geralmente esta ocorre na forma de massas bastante irregulares e dimensões extremamente variáveis (cerca de 0,001 até $3 \mathrm{~mm}$ ).

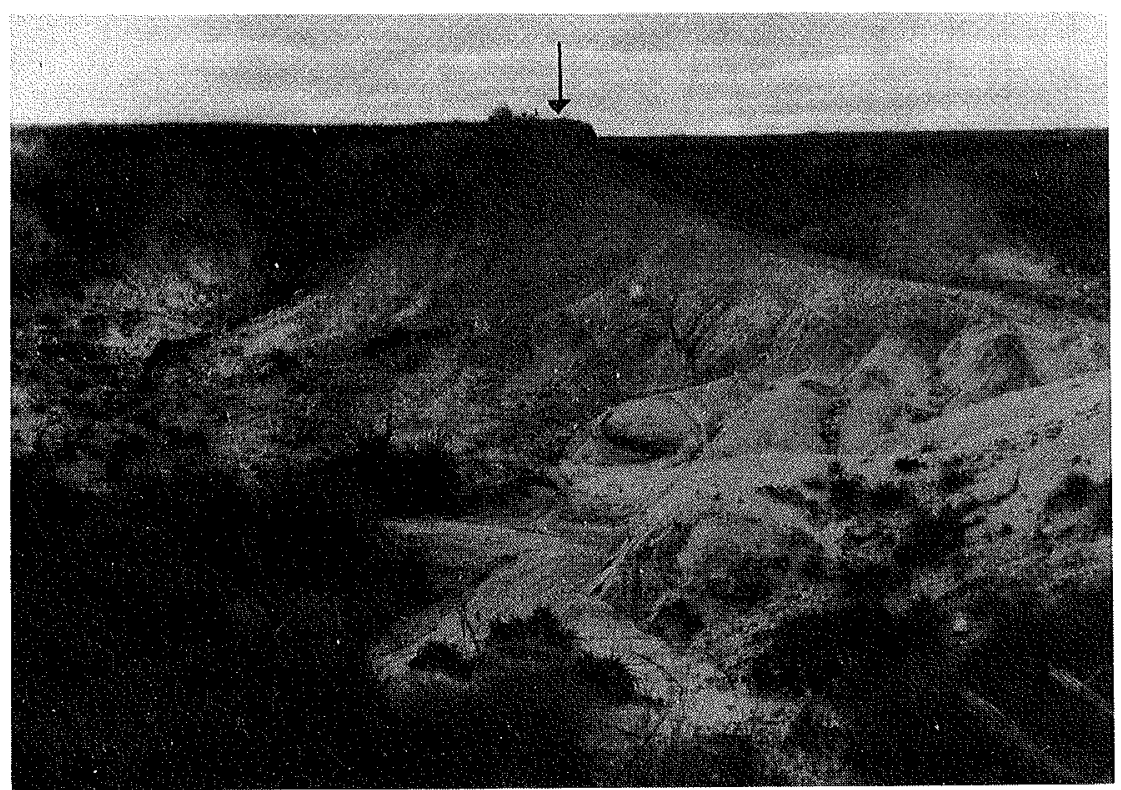

Foto 5 - Vista da Boçoroca Grande, aparecendo ao fundo o perfil n? 1 


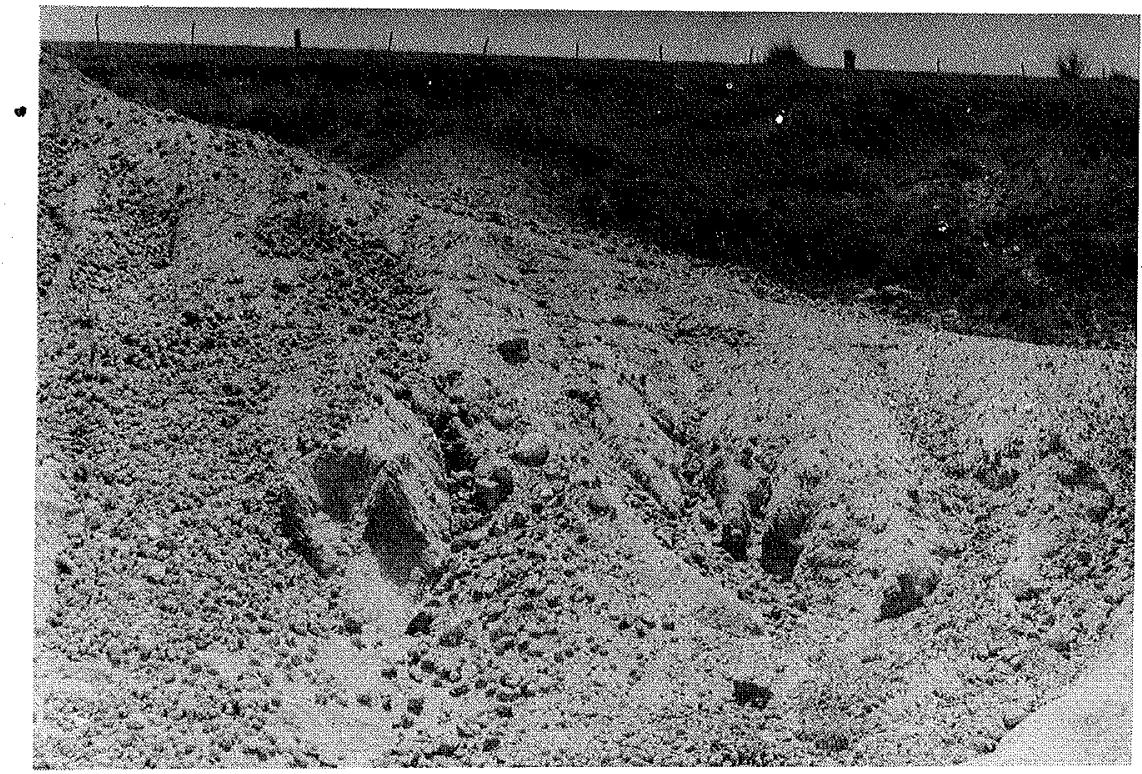

Foto 6 - Horizonte $\mathrm{C}$ do perfil de solo do anortosito com níveis de concreções calcárias

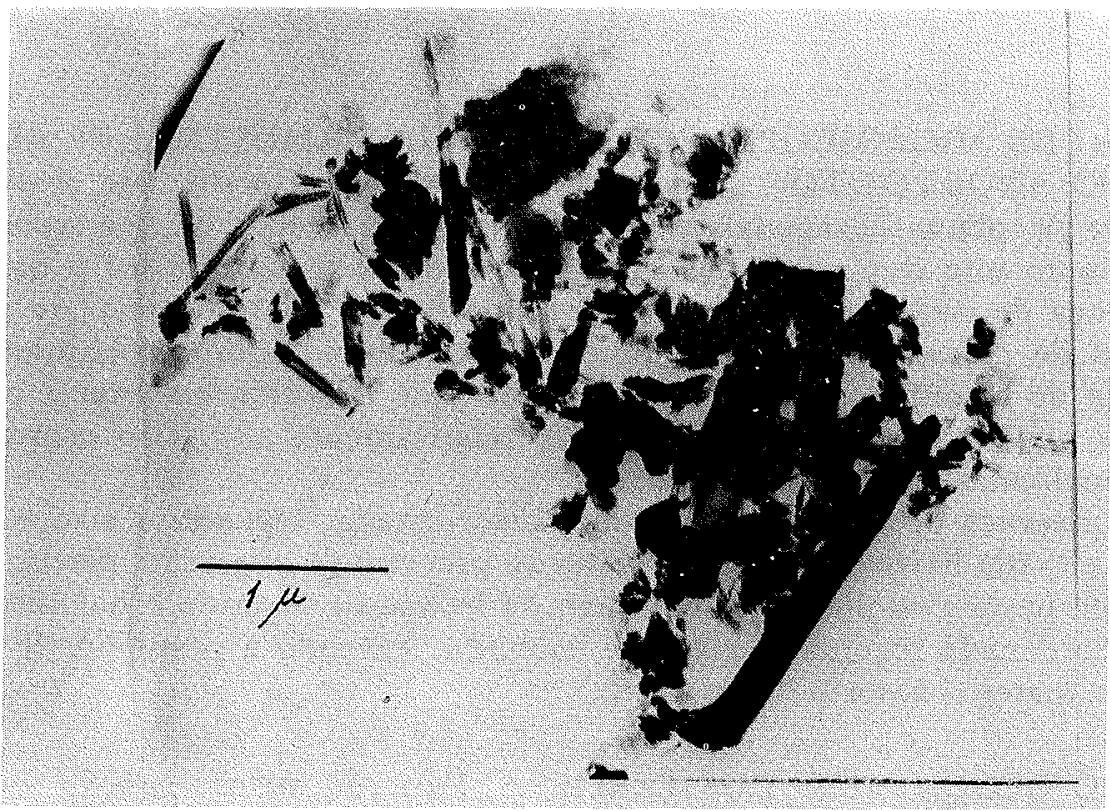

Foto 7 - Eletromicrografia de uma amostra da base do perfil no 6 da Boçoroca Grande. Grandes tubos de haloisita predominam sobre raras placas de caolinita. Os tubos maiores apresentam $2,5 \mu$ de comprimento e $0,2 \mu$ de espessura 


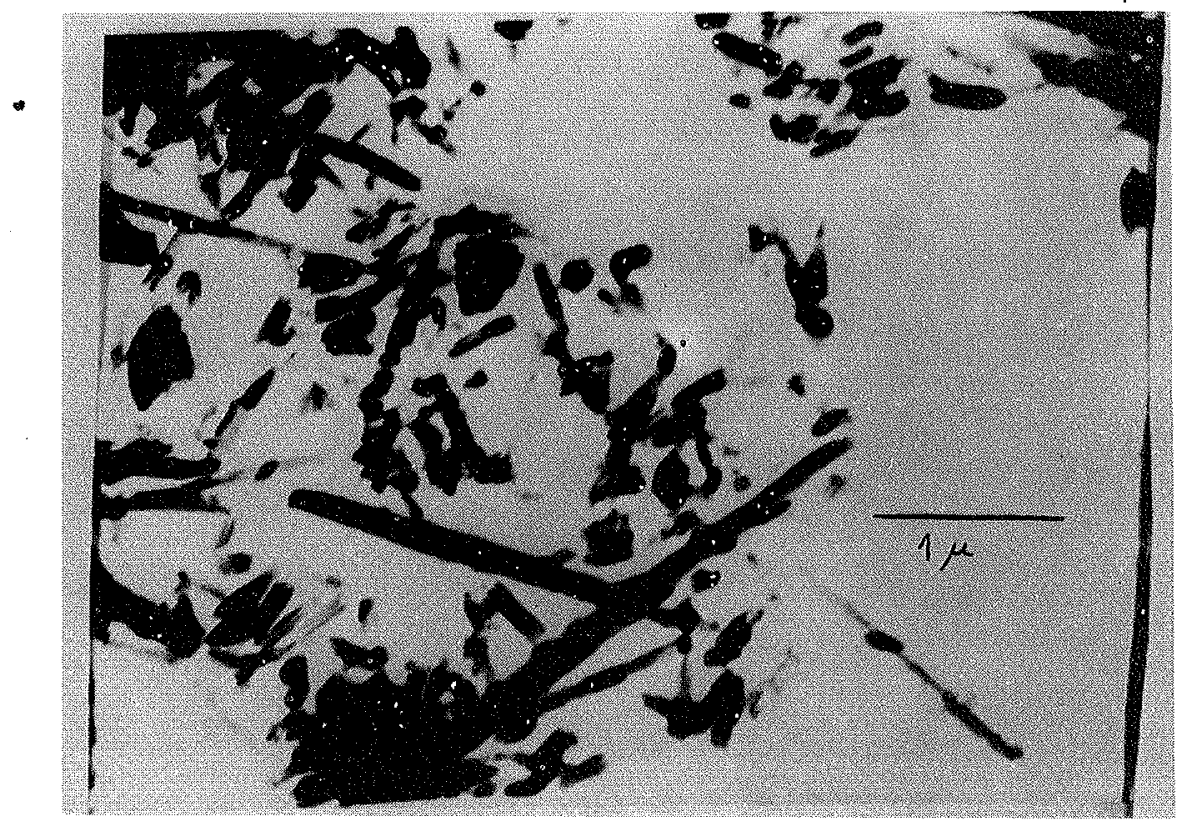

Foto 8 - Eletromicrografia de uma amostra de boçoroca em formação, próxima à Boçoroca Grande. Grandes tubos de haloisita; os maiores com $3 \mu$ de comprimento e $0,25 \mu$ de espessura. Raras placas de caolinita

ESTUDO DA MICROSCOPIA ELETRÔNICA DAS AMOSTRAS DE ALTERAÇÃO DO ANORTOSITO No material alterado dos perfis, não se observa a presença de placas hexagonais com contornos bem definidos, aparecendo estas mais comumente com contornos irregulares e de dimensões de $0,1 \mu$ mostrando a presença de cáolinita desordenada segundo o eixo b. Ainda se pode observar misturas de placas com grandes dimensões ( $3 \mu$ de comprimento), indicando a presença de haloisita. Novikoff (1974) sugere que haloisita se forma a partir de soluções onde a concentração de sílica é relativamente alta, fato ocorrente em águas analisadas na área em estudo.

A presença de haloisita e caolinita desordenada, segundo o eixo $b$, confirmam a elevada lixiviação do plagioclásio no processo de alteração, produzindo resíduos de baixa cristalinidade. A ordem de formação sugerida é haloisita, caolinita desordenada segundo o eixo b e caolinita, havendo a possibilidade da presença de material amorfo (Fotos 7 e 8 ).

ESTUDO GEOQUÍMICO DOS PERFIS Variaçãò da composição normativa dos perfis $\mathrm{O}$ constituinte mais importante, o plagioclásio, é normativamente subdividido em anortita e albita. Da base para o topo do perfil, a anortita diminui em geral de 4 vezes e a albita de 3 vezes. Considerando-se ainda que o cálcio é retido nas concreções e computado no cálculo, como anortita, a destruição da anortita é maior que o valor já referido. (Tab. 1) 
O argilo-mineral predominante é a caolinita (grupo de caolinitas). Apresenta correlação negativa com o plagioclásio, aumentando de 3 vezes para o topo do perfil.

O quartzo aumenta residualmente e irregularmente da base para o topo pela destruicão dos minerais constituintes do anortosito. A presença de quartzo (Garrels e Christ, 1965) preserva a caolinita, evitando posterior alteração à gibsita. Na opinião dos autores, o quartzo foi preservado porque a evolução do material foi incompleta (Fig. 5).

A hematita aumenta regularmente da base para o topo com a oxidação do ferro no perfil, concentrando-se assim superficialmente; seu aumento é, em média, de 3 vezes.

O anatásio normativo representa os minerais de titânio (como ilmenita, rutilo e o próprio anatásio). Aumenta para o topo, por formação intempérica do óxido de titânio ou por preservação da ilmenita.

A ilita aumenta irregularmente para o topo do perfil.

A clorita é produto de alteração dos minerais ferromagnesianos (hornblenda, piroxênio e biotita). Ao longo do perfil, foram encontrados apenas traços desse mineral.

Tabela 1 - Composição normativa das alterações e dos solos do anortosito

Perfil n. 1

Amostra anortita alhita caolinita clorita ilita quartzo hematita anatásio alumina livre

$\begin{array}{rrrllcllll}2 & 10,00 & 8,90 & 31,50 & \text { tr } & 6,60 & 38,60 & 4,20 & 0,90 & - \\ 8 & 15,70 & 4,60 & 47,30 & \text { tr } & 4,80 & 23,90 & 4,00 & 0,40 & - \\ 4 & 18,20 & 11,90 & 41,60 & \text { tr } & 6,30 & 18,50 & 3,60 & 0,50 & - \\ 5 & 25,20 & 17,20 & 25,90 & \text { tr } & 6,50 & 22,70 & 2,90 & 0,30 & - \\ 3 & 40,90 & 22,80 & 30,50 & \text { tr } & 4,30 & - & 1,40 & - & - \\ 12 & 47,50 & 24,90 & 22,00 & \text { tr } & 3,30 & - & 0,90 & - & -\end{array}$

Perfil $n^{\circ} 2$

$\begin{array}{rrrllrrrrc}6 & 10,00 & 7,90 & 50,50 & \text { tr } & 6,50 & 20,00 & 5,00 & 0,60 & - \\ 10 & 12,80 & 5,40 & 61,60 & \text { tr } & 5,50 & 9,50 & 5,50 & 0,40 & - \\ 9 & 19,00 & 9,80 & 35,40 & \text { tr } & 4,90 & 27,00 & 4,20 & 0,30 & 0,60 \\ 11 & 26,50 & 15,60 & 26,50 & \text { tr } & 7,00 & 22,10 & 2,80 & 0,20 & - \\ 1 & 49,10 & 25,90 & 16,40 & \text { tr } & 5,56 & - & 2,50 & 0,10 & - \\ 7 & 51,10 & 40,99 & - & \text { tr } & 6,61 & - & 2,00 & 0,20 & -\end{array}$

Perfil $n^{\circ} 3$

$\begin{array}{rrrllllllll}18 & 12,35 & 7,70 & 42,38 & & \text { tr } & 4,70 & 28,80 & 3,40 & 0,30 & - \\ 19 & 18,24 & 13,50 & 36,90 & \text {. } & \text { tr } & 6,70 & 21,70 & 3,50 & 0,10 & - \\ 20 & 9,90 & 7,90 & 50,50 & & \text { tr } & 6,40 & 20,20 & 5,10 & 0,30 & - \\ 42 & 43,90 & 19,70 & 26,70 & & \text { tr } & 4,10 & 2,20 & 2,90 & - & - \\ 43 & 47,50 & 27,50 & 10,90 & \text { tr } & 4,30 & - & 2,60 & - & 4,70\end{array}$

Obs.: Como as análises químicas dos perfis são similares, apenas três perfis são apresentados nas tabelas. 


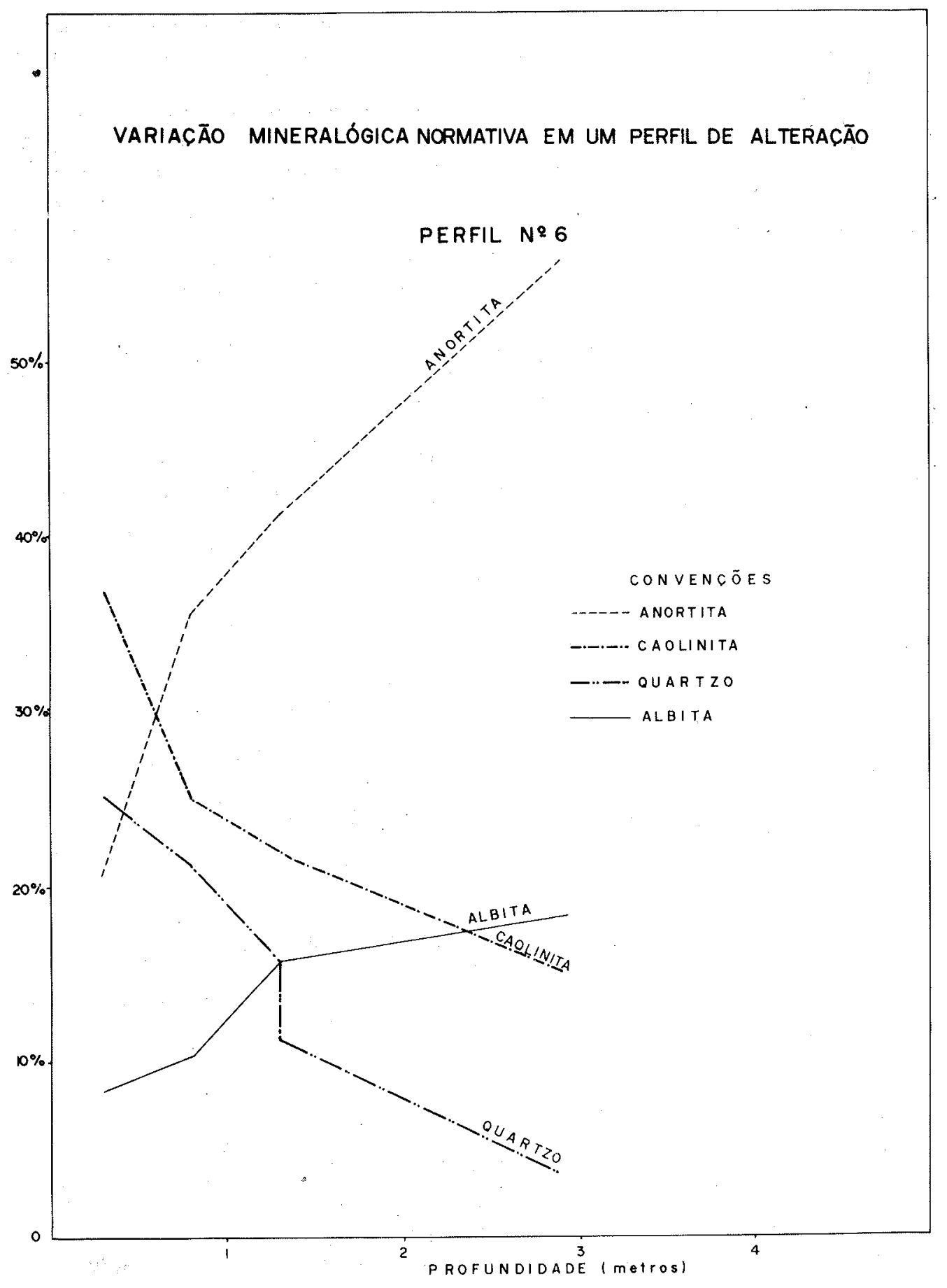

Figura 5 
Diagrama de Ganho e Perda. As variações químicas dos perfis aparecem na Tab. 2. Essas variações podem ser representadas por diagramas ganho e perda. (Fig. 6):

Estes são obtidos a partir do quociente de percentagens dos óxidos constituintes da rocha fresca e dos óxidos constituintes dos resíduos do intemperismo; esse quociente é multiplicado por 100 e colocado em escala logarítmica.

Para este estudo, relacionou-se a percentagem dos óxidos da rocha fresca em local mais próximo possível dos perfis.

A alteração do anortosito é dependente da alteração do plagioclásio; desse fato, resulta a importância da perda de cálcio e sódio. Observa-se que o cálcío e o sódio têm a perda gradativamente aumentada no sentido da base para o topo.

$O$ ferro férrico apresenta um enriquecimento acentuado da base para o topo. Esse provém em parte da oxidação do ferro ferroso da própria rocha. Entretanto, sua elevada concentração no perfil do material alterado em relação à rochạ fresca pode sugerir um aporte de local vizinho.

O alumínio sofre uma pequena perda ou permanece constante. A sílica permanece praticamente constante, mostrando que a destruição do plagioclásio é acompanhada de concentraçāo residual do quartzo ou mesmo que a transformação de labradorita em caolinita se faz sem grandes modificações no conteúdo de sílica.

O potássio, devido a sua baixa concentração, apresenta um comportamento irregular; na rocha menos intemperizada, apresenta perda e, no material mais intemperizado, apresenta um ganho relativo.

Pelos difratogramas de raios $\mathrm{X}$, um dos minerais de potássio presentes no resíduo intemperizado é a ilita. No material mais alterado, com a destruição do plagioclásio, a ilita se enriquece residualmente, explicando o ganho de potássio.

Tabela 2 - Análise química dos perfis de alteração :

\begin{tabular}{|c|c|c|c|c|c|c|c|c|c|c|c|c|c|}
\hline \multicolumn{14}{|l|}{ Perfil n. 1} \\
\hline Amostra & Prof. (m) & $\mathrm{SiO}_{2}$ & $\mathrm{Al}_{2} \mathrm{O}_{3}$ & $\mathrm{CaO}$ & $\mathrm{K}_{2} \mathrm{O}$ & $\mathrm{Na}_{2} \mathrm{O}$ & $\mathrm{Fe}_{2} \mathrm{O}_{3}$ & $\mathrm{FeO}$ & $\mathrm{MgO}$ & $\mathrm{TiO}_{2}$ & $\mathrm{P}_{2} \mathrm{O}_{5}$ & $\mathrm{H}_{2} \mathrm{O}$ & SOMA \\
\hline 2 & 0,20 & 62,40 & 18,66 & 1,85 & 0,75 & 0,96 & 3,74 & 0,08 & 0,25 & 1,19 & 0,03 & 10,88 & 100,79 \\
\hline 8 & 0,70 & 52,42 & 24,63 & 2,73 & 0,51 & 0,47 & 3,47 & 0,06 & 0,17 & 0,29 & 0,02 & 14,96 & 99,73 \\
\hline 4 & 1,00 & 53,99 & 26,14 & 3,35 & 0,71 & 1,27 & 3,28 & 0,06 & 0,29 & 0,54 & 0,02 & 10,33 & 99,98 \\
\hline 05 & 2,00 & 52,21 & 29,60 & 4,77 & 0,75 & 1,89 & 2,76 & 0,06 & 0,20 & 0,31 & 0,02 & 7,96 & 100.53 \\
\hline 3 & 2,50 & 49,03 & 32,61 & 7,90 & 0,47 & 2,55 & 1,36 & 0,06 & 0,22 & tr & 0,06 & 6,23 & 100,49 \\
\hline 12 & 3,00 & 50,46 & 33,93 & 9,58 & 0,41 & 2,91 & 0,95 & 0,04 & 0,10 & 0,05 & 0,07 & 2,36 & 100,85 \\
\hline \multicolumn{14}{|l|}{ Perfil $n .^{\circ} 2$} \\
\hline 6 & 0,20 & 52,62 & 25,54 & 1,78 & 0,71 & 0,82 & 4,37 & 0,07 & 0,25 & 0,58 & 0,02 & 13,57 & 100,33 \\
\hline 10 & 0,60 & 47,18 & 29,32 & 2,26 & 0,60 & 0,55 & 4,83 & 0,07 & 0,17 & 0,80 & 0,01 & 14,74 & 100,55 \\
\hline 9 & 1,00 & 58,52 & 23,84 & 3,58 & 0,56 & 1,07 & 3,31 & 0,06 & 0,29 & 0,39 & 0,09 & 8,89 & 100,60 \\
\hline 11 & 2,10 & 58,15 & 24,26 & 5,05 & 0,82 & 1,73 & 2,68 & 0,05 & 0,28 & 0,36 & 0,01 & 6,81 & 100,20 \\
\hline 1 & 2,50 & 49,86 & $31,75^{\circ}$ & 9,89 & 0,68 & 3,01 & 2,49 & 0,08 & 0,22 & 0,20 & 0,03 & 2,58 & 100,78 \\
\hline 7 & 3,50 & 52,92 & 26,75 & 10,37 & 0,84 & 5,43 & 2,04 & 0,05 & 0,10 & 0,36 & 0,01 & 0,85 & 99,72 \\
\hline \multicolumn{14}{|l|}{ Perfil $n^{\circ} 3$} \\
\hline 18 & 0,30 & 57,93 & 23,53 & 2,25 & 0,53 & 0,82 & 3,05 & 0,04 & 0,23 & 0,45 & 0,017 & 11,69 & 100,53 \\
\hline 19 & 0,80 & 56,21 & 24,50 & 3,37 & 0,76 & 1,45 & 3,15 & 0,05 & 0,29 & 0,29 & 0,017 & 10,01 & 100,09 \\
\hline 20 & 1,00 & 50,28 & 28,47 & 6,58 & 0,48 & 1,92 & 3,03 & 0,04 & 0,41 & 0,18 & 0,025 & 9,90 & 100,61 \\
\hline 42 & 2,50 & 50,22 & 32,07 & 8,76 & 0,51 & 2,28 & 2,89 & 0,03 & 0,34 & 0,05 & 0,026 & 3,43 & 100,60 \\
\hline 43 & 2,90 & 48,43 & 33,21 & 9,57 & 0,90 & 3,18 & 2,58 & 0,08 & 0,38 & nd & 0,026 & 2,38 & 100,73 \\
\hline
\end{tabular}




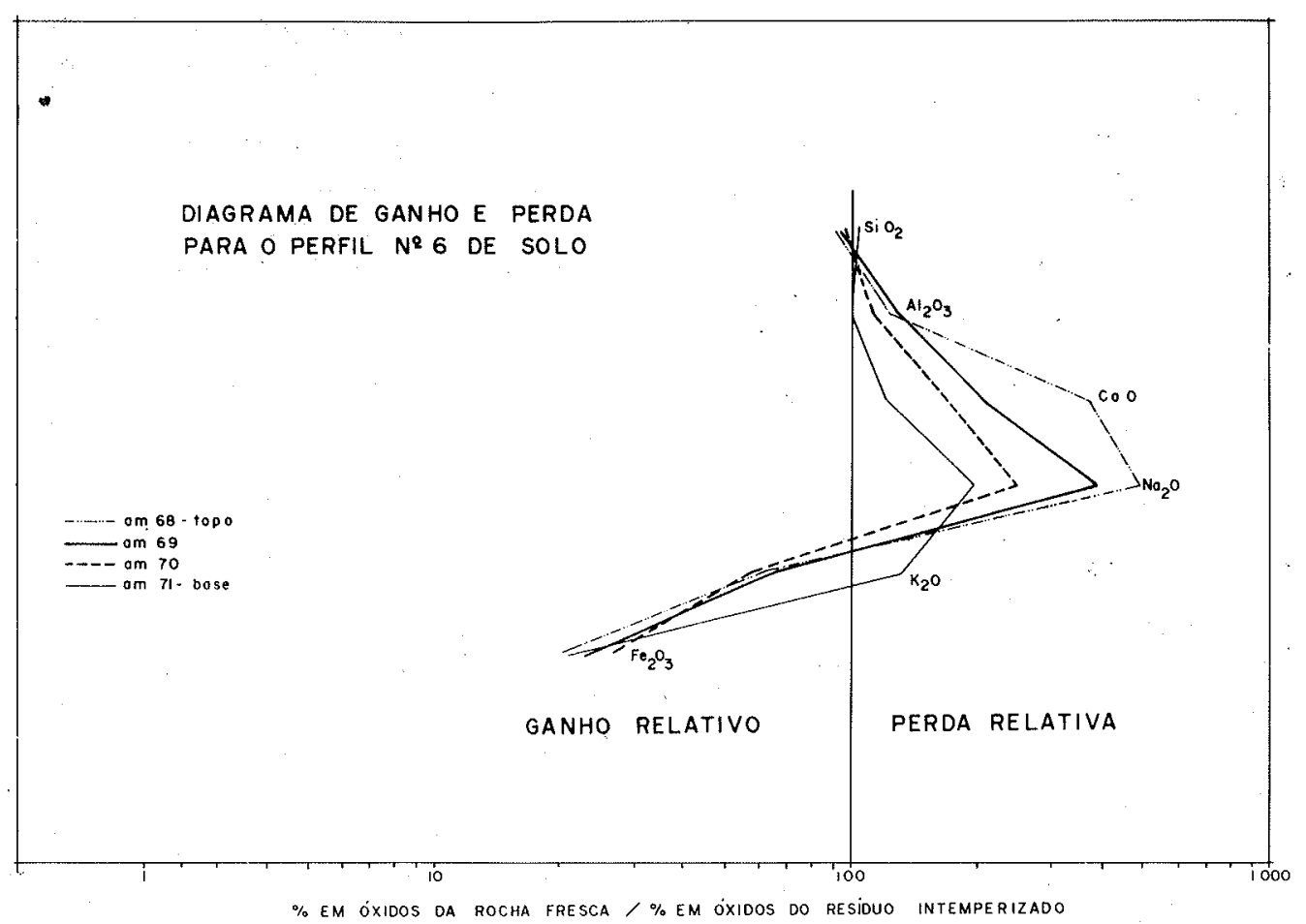

Figura 6

ANÁLISE DE ÁGUA EM EQUILÍBRIO PROVĀVEL COM O MATERIAL DE ALTERAÇÃO DO ANORTOSITO Foram coletadas duas amostras de água. As duas fontes amostradas estão na área de ocorrência da rocha, mas afastadas dos contatos da mesma.

A amostra n. 1 foi coletada num poço de 16 metros de profundidade na Fazenda Porteirinha. A de no 2 de uma fonte aflorante, na Fazenda Sto. Antonio.

Os dados analíticos obtidos para as duas amostras estão apresentadas na Tab. 3.

Tabela 3

\begin{tabular}{|c|c|c|}
\hline & Amostra n. 1* & Amostra $\mathrm{n}^{\circ} \mathbf{2}^{*}$ \\
\hline $\begin{array}{c}\text { ácido ortossilícico } \\
{\left[\mathrm{H}_{4} \mathrm{SiO}_{4}\right]}\end{array}$ & $7,4 \times 10^{4}$ & $8 \times 10^{4}$ \\
\hline Cálcio $\left[\mathrm{Ca}^{+}\right]$ & $3,3 \times 10^{3}$ & $5 \times 10^{4}$ \\
\hline Sódio $\left[\mathrm{Na}^{+}\right]$ & $2,5 \times 10^{3}$ & $3 \times 10^{4}$ \\
\hline Hidrogênio $\left[\mathrm{H}^{+}\right]$ & $10^{8,6}$ & $10^{7.6}$ \\
\hline
\end{tabular}

* concentração molar. 
Os valores de composição das águas foram locados em diagramas bidimensionais, atividade/atividade, $\log \left[\mathrm{H}_{4} \mathrm{SiO}_{4}\right]$ e $\log \frac{\left[\mathrm{Na}^{+}\right]}{\left[\mathrm{H}^{+}\right]}$, comparando com águas oriundas de outras rochas fontes (Garrels e Mackenzie, 1971). A amostra no 2 se situa no campo da caolinita, a amostra n. 1 no campo da montmorilonita prôximo ao limite com o campo da caolinita, mostrando estar também em provável equilíbrio com esta última. (Fig. 7).

Diagrama ATIV./ATIVI PARA $\mathrm{O}$ SISTEMA $\mathrm{Ne}_{2} \mathrm{O}-\mathrm{Al}_{2} \mathrm{O}_{3}-$ $\mathrm{SiO}_{2}-\mathrm{H}_{2} \mathrm{O}$ A $25^{\circ} \mathrm{C}$ E 10 otm.

anAlises de aquas associadas a rochas íneas loca.

DAS NO DIAGRAMA.

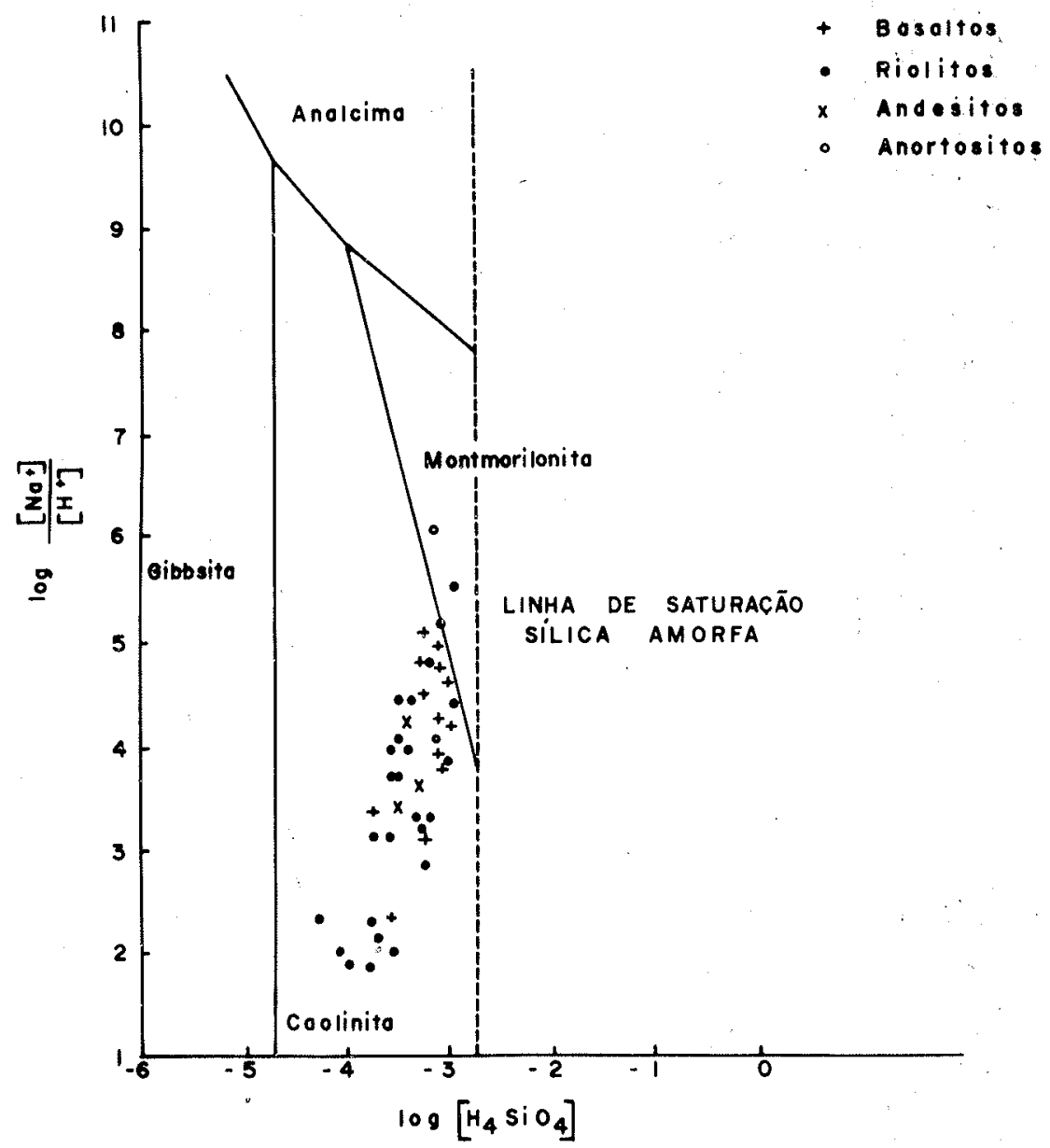

Figura 7 
No segundo diagrama bidimensional atividade/atividade, $\log \left[\mathrm{H}_{4} \mathrm{SiO}_{4}\right]$ e $\log$ $\frac{\left[\mathrm{Ca}^{++}\right]}{\left[\mathrm{H}^{+}\right]^{3}}$, os valores aparecem na Tabela 4 (Fig. 8).

Tabela 4

\begin{tabular}{|c|c|c|}
\hline & $\log \left[\mathrm{H}_{4} \mathrm{SiO}_{4}\right]^{*}$ & $\log \frac{\left[\mathrm{Ca}^{++}\right]^{*}}{\left[\mathrm{H}^{+}\right]^{3}}$ \\
\hline amostra $\mathbf{n}^{\circ} \mathrm{l}$ & $-3,1$ & $+14,7$ \\
\hline amostra $\mathbf{n}^{\circ} 2$ & $-3,1$ & $+13,9$ \\
\hline
\end{tabular}

* concentração molar.

Os valores para as amostras de água se situaram no campo da montmorilonita, mostrando que, em profundidade, talvez esse argilo-mineral esteja presente como está na base dos perfis, enquanto, em superfície, a ocorrência de caolinita é um fato conhecido.

DIAGRAMA ATIV/ATIV PARA O SISTEMA $\mathrm{COO}-\mathrm{Al}_{2} \mathrm{O}_{3}-\mathrm{SIO}_{2}-$

$\mathrm{H}_{2} \mathrm{O}$ A $25^{\circ} \mathrm{C}$ E I Otm.

ANÁLISES DE ÁGUAS ASSOCIADAS A RNCHAS IGNEAS LOCA.

DAS NO DIAGRAMA.

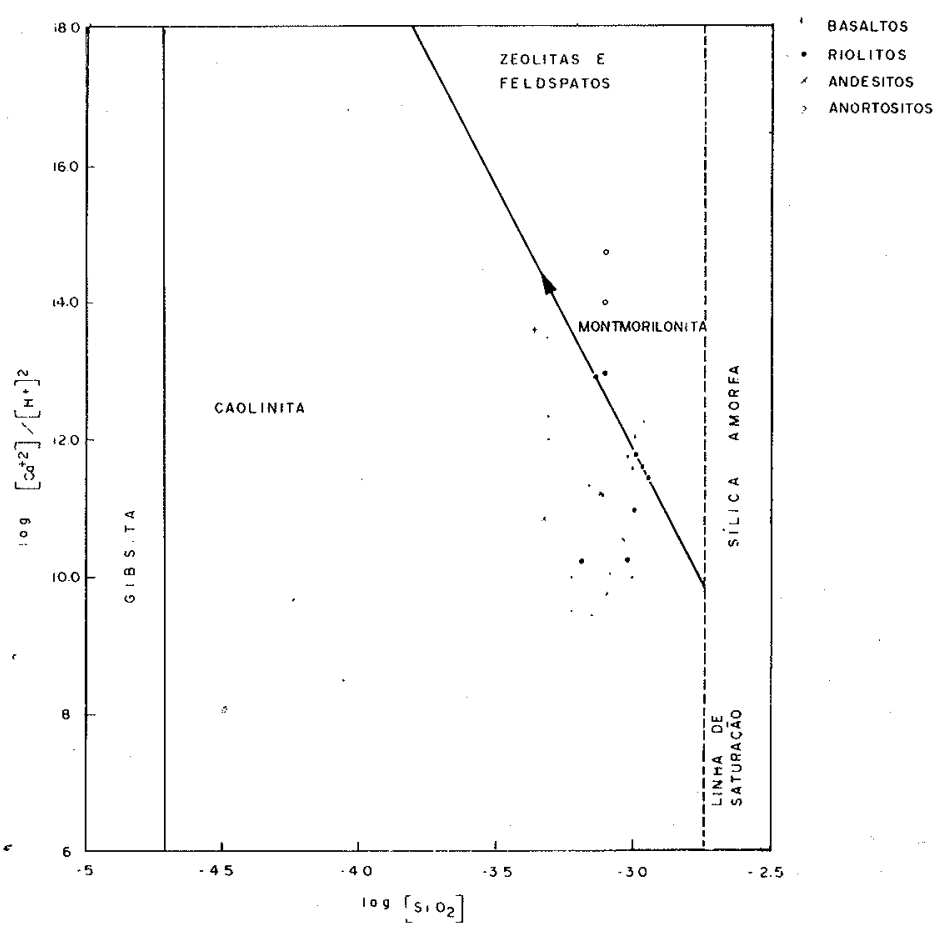

Figura 8 
CONDIÇÕES FÍSICO-QUÍMICAS DE ALTERAÇÃO

Pelo estudo de campo e de laboratório, observa-se a alteração da labradorita à caoliníta diretamente, embora em alguns perfis, se determine uma fase intermediária esmectítica.

A alteração da labradorita à caolinita se dá segundo a seguinte equação:

$$
\begin{aligned}
& \mathrm{Na}_{0,5} \mathrm{Ca}_{0,5} \mathrm{Al}_{1,5} \mathrm{Si}_{2,5} \mathrm{O}_{\mathrm{s}_{\mathrm{s},}}+1,5 \mathrm{H}_{\text {aq. }}^{+}+2,75 \mathrm{H}_{2} \mathrm{O}_{\text {liq. }}= \\
& \text { labradorita } \\
& =0,5 \mathrm{Na}_{\text {aq. }}^{+}+0,5 \mathrm{Ca}_{\text {aq. }}^{++}+\mathrm{H}_{4} \mathrm{SiO}_{4 \text { aq. }}+0,75 \mathrm{Al}_{2} \mathrm{Si}_{2} \mathrm{O}_{5}(\mathrm{OH})_{4_{\mathrm{s}}} \\
& \text { (caolinita) }
\end{aligned}
$$

A labradorita é o principal mineral do anortosito. O principal mineral de alteração é caolinita. Considera-se, no caso, as misturas de caolinita e haloisita como representadas exclusivamente por caolinita, já que as energias livres de formação não diferem muito. Os íons $\mathrm{Na}^{+}$e $\mathrm{Ca}^{++}$e parte do silício, na forma $\mathrm{H}_{4} \mathrm{SiO}_{4}$, são lixiviados. A alteração é facilitada pela acidez do meio como mostra a equação. Os horizontes do perfil apresentam pH ácido $(5,2-6,5)$, mostrando que haveria facilidade para a alteração da caolinita. $O$ cálcio é parcialmente retido nas concreções calcárias que se formam no horizonte arenoso cinza-claro do solo, mas certamente a maior parte do cálcio e do sódio são lixiviados. Se esses cátions forem totalmente lixiviados e parte da sílica também, a labradorita se altera completamente em caolinita. Locando em diagrama tridimensional, $\mathrm{H}_{4} \mathrm{SiO}_{4}, \log$ $\frac{\left[\mathrm{Ca}^{+2}\right]}{\left[\mathrm{H}^{+}\right]^{3}}$ e $\log \frac{\left[\mathrm{Na}^{+}\right]}{\left[\mathrm{H}^{+}\right]}$as análises de águas em equilíbrio com o anortosito, observa-se que as composições das mesmas se situam no campo da caolinita, o mineral a ser formado.

ESTUDOS DA VARIAÇÃO DE ESTRÔNCIO, BĀRIO E OUTROS ELEMENTOS MENORES NOS PERFIS DE ALTERAÇÃO DO ANORTOSITO DE CAPIVARITA 1 -Estrôncio Durante o intemperismo, teoricamente o estrôncio deve acompanhar o cálcio. Esse fato ficou também comprovado pelo estudo feito pelos autores nos perfis de alteração dos solos.

A variação do estrôncio, bário e cálcio nos perfis de alteração do anortosito de Capivarita são apresentados na Tab. 5.

As concentrações de estrôncio variam de $70 \mathrm{ppm}$ a $1.020 \mathrm{ppm}$, respectivamente, a partir do horizonte do solo cinza escuro a preto à rocha parcialmente alterada.

No processo de alteração da labradorita em caolinita, o cálcio é lixiviado assim como o sódio. A formação de concreções no horizonte $\mathrm{C}$ mostra que o cálcio lixiviado é em parte precipitado como carbonato. Foi testada a possibilidade das mesmas fixarem o estrôncio, o que foi comprovado através de ensaio feito em uma amostra de concreção. $O$ resultado obtido foi de aproximadamente $100 \mathrm{ppm}$ de estrôncio.

Conclui-se, por este dado, que a migração do estrôncio é similar à migração do cálcio. Ambos são lixiviados do plagioclásio, precipitando como carbonato nas concreções e o restante é carreado em solução. (Fig. 9). 
Tabela 5 - Valores analíticos para cálcio, estrôncio e bário e razão cálcio-estrôncio. Perfil n. $^{\circ}$

\begin{tabular}{|c|c|c|c|c|c|}
\hline Amostra & Prof. (m) & $\% \mathrm{Ca}$ & Sr (ppm) & $\mathrm{Ba}(\mathrm{ppm})$ & $\frac{\mathrm{Ca}}{\mathrm{Sr}}$ \\
\hline 2 & 0,20 & 1,85 & 90 & 230 & 205 \\
\hline 8 & 0,70 & 2,73 & 130 & 140 & 210 \\
\hline 4 & 1,00 & 3,35 & 150 & 240 & 223 \\
\hline 5 & 2,00 & 4,77 & 280 & 210 & 170 \\
\hline 3 & 2,50 & 7,90 & 460 & 230 & 171 \\
\hline 12 & 3,00 & 9,58 & 500 & 270 & 191 \\
\hline \multicolumn{6}{|l|}{$r f i l n^{\circ} 2$} \\
\hline 6 & 0,20 & 1,78 & 70 & 320 & 254 \\
\hline 10 & 0,60 & 2,26 & 100 & 300 & 226 \\
\hline 9 & 1,00 & 3,58 & 150 & 420 & 238 \\
\hline 11 & 2,10 & 5,05 & 270 & 270 & 187 \\
\hline 1 & 2,50 & 0,89 & 710 & 290 & 139 \\
\hline 7 & 3,50 & 10,37 & 980 & 230 & 105 \\
\hline \multicolumn{6}{|l|}{ rfil $n .^{\circ} 3$} \\
\hline 18 & 0,30 & 2,25 & 160 & 250 & 140 \\
\hline 19 & 0,80 & 3,37 & 270 & 170 & 124 \\
\hline 20 & 1,00 & 6,58 & 320 & 370 & 205 \\
\hline 42 & 2,50 & 8,76 & 520 & 190 & 168 \\
\hline 43 & 2,90 & 9,57 & 640 & 280 & 149 \\
\hline
\end{tabular}

ppon $\mid \mathrm{sr})$

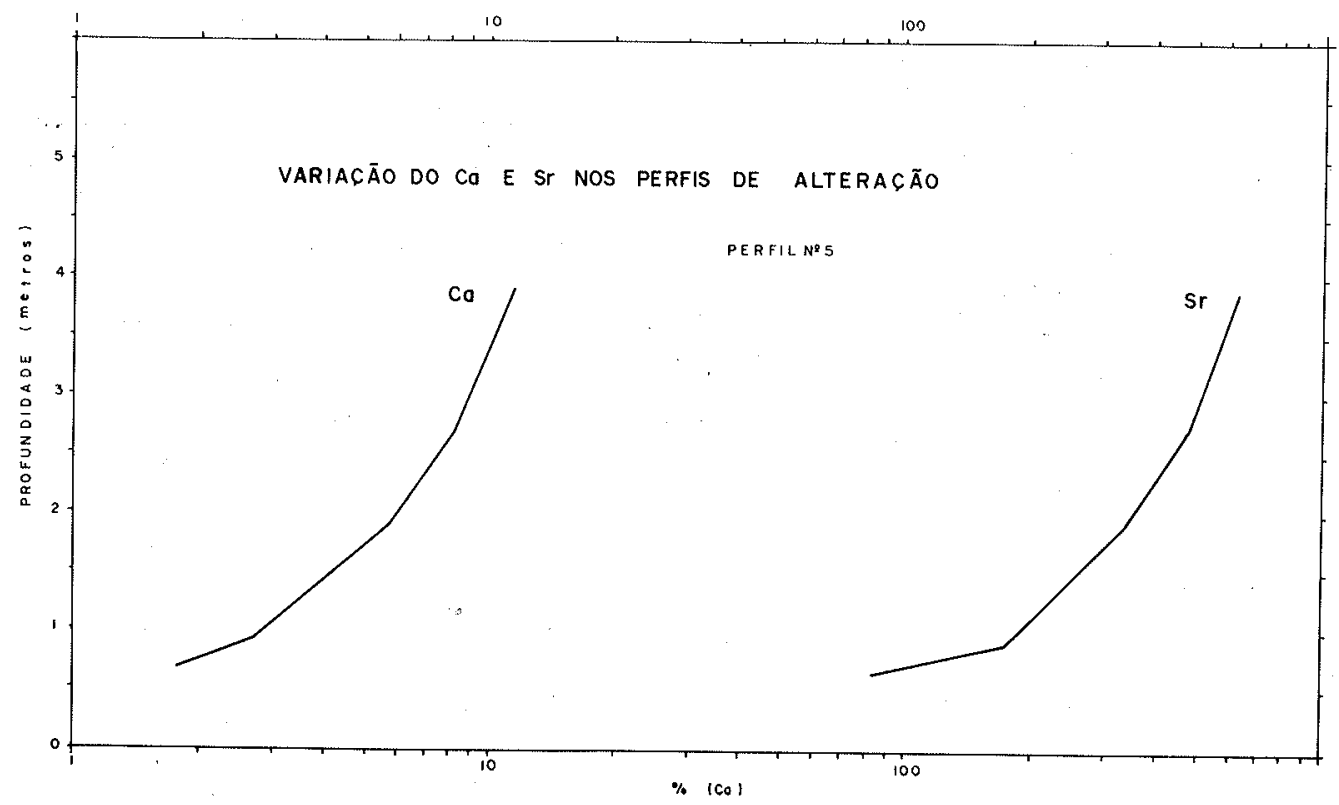

Figura 9 
Um estudo de detalhe na variação de teores de cálcio e estrôncio foi realizado em uma amostra encontrada na mina de caolim de Dois Cerros (foto 9). O material mostrava no centro um seixo de anortosito fresco de aproximadamente $4 \mathrm{~cm}$ em seu diâmetro maior. Este aparecia envolvido por uma crosta de material alterado de $6 \mathrm{~cm}$, constituída de caolim, comprovando assim a alteração intempérica do anortosito a caolim.

A partir do centro da amostra até a periferia, foram feitas seis divisões de aproximadamente $1,5 \mathrm{~cm}$ e em cada divisão foi feita a análise dos teores de cálcio e estrôncio e a determinação mineralógica por difração de raios $\mathrm{X}$ das frações $<2 \mu, 2-20 \mu$ e $20-60 \mu$. Os resultados obtidos foram (Tab. 6):

Tabela 6

\begin{tabular}{|c|r|r|}
\hline Amostra & Sr & Ca \\
\hline (anort.) n: 1 & 750 & $11,05 \%$ \\
(anort.) n: 2 & 750 & $9,90 \%$ \\
(anort.) n: 3 & 750 & $9,02 \%$ \\
(caolim) n: 4 & 50 & $4,73 \%$ \\
(caolim) n: 5 & 50 & $3,18 \%$ \\
(caolim) n: 6 & 50 & $1,73 \%$ \\
\hline
\end{tabular}

Examinando os resultados, observa-se o paralelismo da variação de cálcio e estrôncio da rochà fresca para o material alterado.

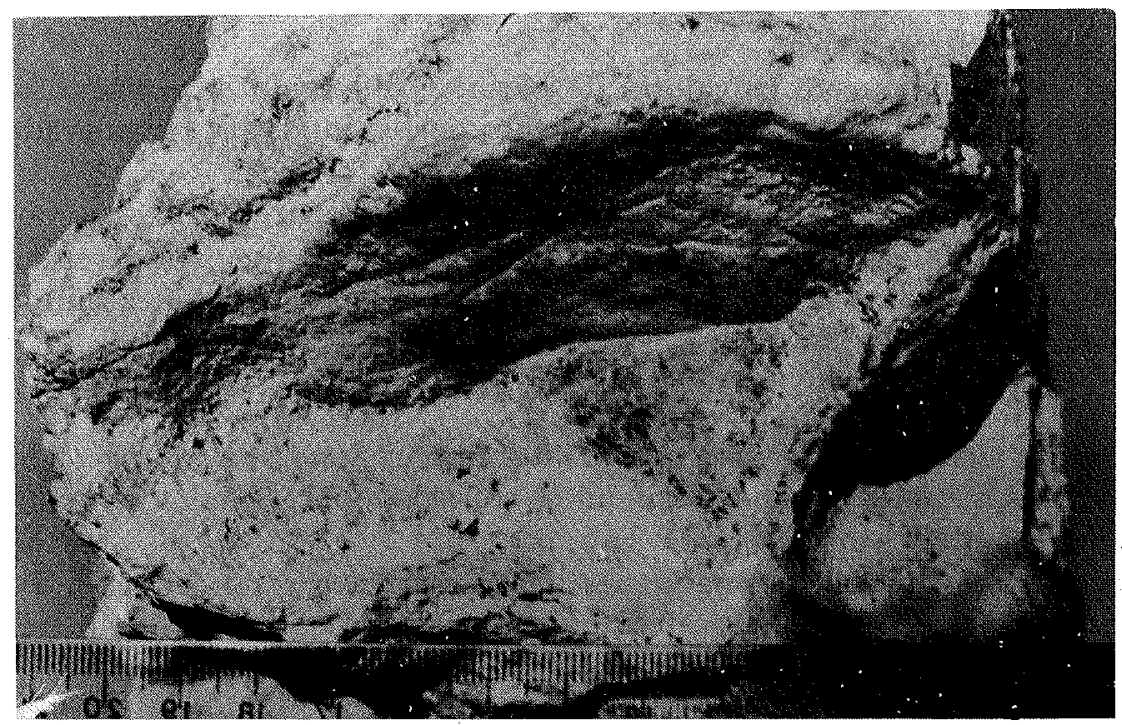

Foto 9 - Seixo de anortosito, constituindo o núcleo da massa de caolim. (Dois Cerros, pivarita, Rio Pardo, RS) 
Ainda, da parte alterada, foi feita separação granulométrica. As frações $<2 \mu$, $2-20 \mu, 20-60 \mu$ foram analisadas. Os dados para estrôncio aparecem abaixo. (Tab. 7)

Tabela 7

\begin{tabular}{|c|c|c|c|}
\hline & fração $<2 \mu$ & $2-20 \mu$ & $20-60 \mu$ \\
\hline Am. n: 4 & nd & $10 \mathrm{ppm}$ & $35 \mathrm{ppm}$ \\
\hline Am.n:5 & nd & $10 \mathrm{ppm}$ & $30 \cdot \mathrm{ppm}$ \\
\hline Am. n: 6 & nd & $10 \mathrm{ppm}$ & $25 \mathrm{ppm}$ \\
\hline
\end{tabular}

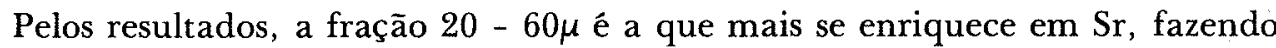
supor que esse elemento esteja incluído nos grãos finos de plagioclásio.

2 - Bário Nos perfis de alteração do anortosito, foi estudada a variação do bário, com o objetivo de comparar seu possível relacionamento com a variação do cálcio e do estrôncio.

$\mathrm{Na}$ Tab. 5 aparecem os valores de bário. O intervalo de concentração para este elemento foi de 140 ppm a 510 ppm nos perfis, intervalo considerado pequeno se comparado com a variação de estrôncio.

Para a maioria dos perfis, os valores encontrados para bário são maiores que os de estrôncio, fato já evidenciado por Vinogradov (1959) e explicável pela maior lixiviação ou na adsorção do bário pelos argilo-minerais ou outros minerais das fraçōes finas.

3 - Outros elementos menores de menor importância nos perfis de alteração Os elementos menores, cromo, manganês, coḅre, níquel, cobalto e zircônio foram analisados e os dados aparecem na Tab. 8.

O aumento do teor de manganês da base para o topo é devido à provável fixação deste elemento. Os leves enriquecimentos de cobre e cobalto podem ser explicados através do elevado teor de matéria orgânica no horizonte $A$.

$O$ zircônio tem probabilidade de se enriquecer residualmente pela baixa solubilidade de seus minerais. O cromo também sofre leve enriquecimento para o topo do perfil; podendo ser atribuido à adsorção já que a presença de cromita é pouco provável. O níquel apresenta um comportamento irregular ao longo dos perfis. 
Tabela 8 - Elementos menores nos perfis de alteração

\begin{tabular}{|c|c|c|c|c|c|c|}
\hline \multicolumn{7}{|l|}{ Perfil $n^{\circ} 1$} \\
\hline Amostra & $\mathrm{Cr}^{* *}$ & $\mathrm{Mn}^{*}$ & $\mathrm{Cu}^{* *}$ & $\mathrm{Ni}^{* *}$ & $\mathrm{Co}^{* *}$ & $\mathrm{Zr}^{* *}$ \\
\hline 2 & 11 & 0,06 & 11 & 2 & 20 & 40 \\
\hline 8 & 10 & 0,01 & 7 & 5 & 4 & 20 \\
\hline 4 & 8 & 0,09 & 5 & 4 & 6 & 100 \\
\hline 5 & 6 & 0,03 & 8 & 4 & 9 & 80 \\
\hline 3 & 2 & 0,01 & 2 & 2 & nd & 10 \\
\hline 12 & 2 & 0,01 & 2 & 2 & nd & nd \\
\hline \multicolumn{7}{|l|}{ Perfil $n^{\circ} 2$} \\
\hline 6 & 16 & 0,01 & 7 & 8 & 12 & 30 \\
\hline 10 & 35 & 0,07 & 8 & 6 & 14 & 15 \\
\hline 9 & 9 & 0,06 & 4 & 5 & 7 & 20 \\
\hline 11 & 8 & 0,03 & 2 & 2 & 5 & 30 \\
\hline 1 & 30 & 0,07 & 2 & 10 & 18 & 10 \\
\hline 7 & 2 & 0,01 & 2 & 2 & 2 & nd \\
\hline \multicolumn{7}{|l|}{ Perfil n. 3} \\
\hline 18 & 8 & 0,05 & 9 & 8 & 16 & 40 \\
\hline 19 & 7 & 0,12 & 5 & 5 & 16 & 35 \\
\hline 20 & 6 & 0,11 & 4 & 15 & 20 & 20 \\
\hline 42 & 2 & 0,02 & 2 & 10 & 18 & 15 \\
\hline 43 & 5 & 0,01 & 2 & 2 & 5 & 5 \\
\hline
\end{tabular}

CONCLUSÕES 1. Pelas características morfológicas, os solos de anortosito são classificados no grande grupo dos Brunizem hidromórficos.

2. Para os diversos horizontes, nos perfis de alteração do anortosito, a fração argila é constituída exclusivamente por minerais do grupo da caolinita (caolinita, caolinita desordenada segundo o eixo b e haloisita). Nas frações de granulometria maior, predominam quartzo e plagioclásio.

3. Da base para o topo do perfil, a anortita normativa diminui, em geral, 4 vezes; a albita normativa 3 vezes, mostrando que o cálcio é mais facilmente lixiviado que o sódio. O quartzo aumenta residualmente e irregularmente da base para o topo. A hematita aumenta regularmente da base para o topo.

4. Através da microscopia eletrônica do material alterado não se observou placas hexagonais com contornos bem definidos, aparecendo estas mais comumente com contornos irregulares, sugerindo a presença de caolinita desordenada segundo o eixo b. Para muitas amostras, aparecem grandes tubos, evidenciando a presença de haloisita.

5. A alteração de labradorita à caolinita se dá segundo a seguinte equação:

$$
\begin{aligned}
& \mathrm{Na}_{0,5} \mathrm{Ca}_{0,5} \mathrm{Al}_{1,5} \mathrm{Si}_{2,5} \mathrm{O}_{8}+1,5 \mathrm{H}^{+}{ }_{\text {aq. }}+2,75 \mathrm{H}_{2} \mathrm{O}_{\text {liq. }}= \\
& \quad \text { (labradorita) } \\
& =0,5 \mathrm{Na}^{+}{ }_{\text {aq. }}+0,5 \mathrm{Ca}^{++}{ }_{\text {aq. }}+\mathrm{H}_{4} \mathrm{SiO}_{4 \text { aq. }}+{ }^{+}+\underset{\mathrm{Al}_{2} \mathrm{Si}_{2} \mathrm{O}_{5}(\mathrm{OH})_{4 .}}{\text { (caolinita) }}
\end{aligned}
$$

A alteração é facilitada pela acidez do meio.

A caolinita é o principal mineral formado pela intemperização do anortosito. 
6. Locados em diagrama bidimensional, com coordenadas $\log \left[\mathrm{H}_{4} \mathrm{SiO} \mathrm{O}_{4}\right]$ e $\log$ $\frac{\left[\mathrm{Na}^{\prime}\right]}{\left[\mathrm{H}^{\bullet}\right]}$, dados analíticos de duas águas, em provável equilíbrio com os produtos de alteração do anortosito, levaram a observar que a composição de uma amostra se situa no campo da caolinita e a outra, no campo da montmorilonita, próximo ao campo da caolinita. Dessa forma, o argilo-mineral em equilíbrio, e que tenderia a se formar, seria a caolinita.

7. Em um diagrama bidimensional, tendo como coordenadas $\log \left[\mathrm{H}_{4} \mathrm{SiO}_{4}\right]$ e $\log \frac{[\mathrm{Ca}]}{[\mathrm{H}]^{2}}$, observa-se que as amostras de água se situam no campo da montmorilonita mostrando que, em profundidade, talvez esse argilo-mineral esteja em equilíbrio, como está presente em pequena quantidade na base dos perfis.

8. Em um diagrama tridimensional, cujas ordenadas são $\log \left[\mathrm{Na}^{+}\right], \log \left[\mathrm{H}_{4} \mathrm{SiO}_{4}\right]$ e $\log \frac{\left[\mathrm{Ca}^{-}\right]}{\left[\mathrm{H}^{3}\right]^{3}}$ um plano divide os campos de estabilidade da caolinita. (parte interna) e labradorita (parte externa). A diminuição dos valores de $\log \left[\mathrm{Na}^{+}\right], \log$ $\left[\mathrm{H}_{4} \mathrm{SiO}_{4}\right]$ e de $\log \underset{\left[\mathrm{Ca}^{++}\right]}{\left[\mathrm{H}^{+}\right]}$conduz à alteração de labradorita à caolinita.

9. O estrôncio ao longo dos perfis varia de 1.020 a $70 \mathrm{ppm}$ da base para o topo. Durante o intemperismo, esse elemento apresenta um comportamento muito similar ao cálcio. O comportamento do bário difere daquele do estrôncio.

BIBLIOGRAFIA

FORMOSO, M.L.L. e CARRARO, C.C. - 1962 - A Caolinização do Anortosito de Capivarita. Nota apresentada no XVI Congresso Brasileiro de Geologia, Porto Alegre. FORMOSO, M.L.L., CARRARO, C.C. e HERZ, N. - 1966 - The Anorthosite of Capivarita. Annual Meeting of the Geol. Soc. of America, EEUU.

FORMOSO, M.L.L. e CARRARO, C.C. - 1968 - Anortosito de Capivarita, Rio Pardo, RS. An. Acad. Bras. Ciências, 40(3) : 361-372.

FORMOSO, M.L.L. - 1972 - Geologia da Folha de Capivarita. Tese de Doutoramento. USP.

GARRELS, R.M., and CHRIST, C.L. - 1965 - Solutions, Minerals, and Equilibria, Harper e Row, New York.

GARRELS, R.M., MACKENZIE, F.T. - 1971 - Evolution of Sedimentary Rocks, W. W. Nórton \& Company, Inc., New York, 135-174.

HARRASSOWITZ, A. - 1962 - Laterit. Fortschr. Geol. Paleontologie, Berlin, 4: 253-565.

HERZ, N. and IUUTRA, C.V. - 1960 - Minor Element Abundance in Part of the Brazilian Shield. Geochim. et Cosmoch. Acta, 21. (1-2) : 81-98.

LEVI, F., MELFI, A.J. - 1972 -- Geochemical and Mineralogical studies on the first stages of weathering of basic and related rocks. Part 2. Rev. Bras. Geoc. 2. (1) : 1-17.

MELFI, A.J., PEDRO, G. 1974 - Étude sur L'altération experimentale de silicates magnésifères et la formation exogène des gisements de magnese. Bull. Groupe Franç. Argiles, t. XXVI : 91-105.

MELFI, A.J., PEDRO, G., NALOVIC, L., QUEIROZ NETO, J.P. - 1976 - Étude sur L'altération géochimique des itabirites du Brésil -. Dissolution du quartz et instabilité de l'hématite primaire en conditions tropicales hydrolysantes. Cah. ORSTOM, sér Pédol., vol. XIV. (3) : 179-192.

MONIZ, A.C., NASCIMENTO, A.C. e PAIVA NETO, J.E. - 1973 - Mobilidade dos constituintes de rochas básicas de São Paulo durante o intemperismo. Rev. Bras. Geoc. 3 (3) : 201-213. 
PEDRO, G. - 1964 - Contribuition a L'étude Expérimentale de L'altération géochimique des Roches Cristallines. Tese de Doutoramento. Faculté des Sciences de L'Université de Paris.

PICADA, R.S. e TESSARI, R.I. - 1966 - Geologia da Folha de Piquiri DFPM do DNPM, Porto Alegre (rel. interno).

ROISENBERG, A. - 1974 - "Argilo-Minerais em Rochas Basálticas Frescas; Mineralogia dos Estádios Primários de Intemperismo de Rochas Basálticas". Tese de Mestrado. UFRGS.

SARTORI, P.L., MACIEL Fo, C. e MENEGOTTO, E. - 1973 - Contribuição ao Estudo das Rochas Basálticas e seus Produtos de Alteração. Região de Santa Maria, RS. Departamento de Geociências. Centro de Estudos Básicos, UFSM, RGS.

SIGHINOLFI, G.P.; AZEVEDO, L.S.P., LINHARES, P.S., and MONIZ, A.C. - 1973 Mineralogical and chemical variations induced by tropical weathering of granulitic rocks from the Brazilian basement. Rev. Bras. Geoc., 3 (2) : 71-83.

SILVA Fo, B.C. - 1972 - Alguns dados sobre o intemperismo e a Mineralogia das Argilas dos Basaltos e dos seus Solos Residuais. Tese de Mestrado. UFRGS.

SMITH, J.R. and GAY, P., - 1958 - The power and lattice parameters of Plagioclase feldspars, Min. Mag. II, 131 : 744-762. 